\title{
An Investment Strategy Based on Life and Business Cycles*
}

\author{
Hyoung-Goo Kang, Professor, Hanyang University \\ Kyoung-Hun Bae ${ }^{* *}$, Professor, Hanyang University \\ Sung-Taek Yang, Master's Student, Hanyang University \\ Chang-Hee Choi, Ph.D Student, Hanyang University
}

\begin{abstract}
$\langle$ Abstract $\rangle$
This study develops an investment strategy that considers both the life cycle and the business cycle by investing in the market index of emerging and global markets (called the Business and Life Cycle Fund (BLCF)). Considering the change in investors' risk capacity depending on their age, we propose a model similar to the Target Date Fund (TDF), that incorporates the life cycle. We also incorporate the business cycle into the model for excess returns, which leads the model to invest more in emerging markets during economic booms and to shift the portfolio's weight to the global market during recessions. To mitigate market risk, we include additional assets that move in an opposite direction to business cycles. The resulting model provides higher annual returns and a higher Sharpe ratio than does the model that encompasses only the life cycle model and other market indices individually. In addition, a model that considers risk hedging shows higher annual returns and a higher Sharpe ratio than does the model encompassing only the business and life cycles. These results contribute to future TDF modeling as well as to Korean policymakers' default option decision issue.
\end{abstract}

Keywords: TDF; BLCF; Business Cycle; Business Reversible Assets; Default Options

JEL Classification: G1

* This research was supported by New Scholars Grant Program from the Korean Securities Association and Mirae Asset in 2018.

** Corresponding Author. Address: Business Administration, Hanyang University, 222, Wangsimni-ro, Seongdong-gu, Seoul, Korea 04763; E-mail: khbae@hanyang.ac.kr; Tel: +82-2-2220-1044; Fax: +82-2-2220-1169.

Received: March 9, 2019; Revised: August 12, 2019; Accepted: September 17, 2019 


\title{
생애주기와 경기변동주기를 이용한 투자전략
}

\author{
강 형 구 (한양대학교 교수) \\ 배 경 훈 (한양대학교 교수)** \\ 양 성 택 (한양대학교 석사과정) \\ 최 창 희 (한양대학교 박사과정)
}

\begin{abstract}
본 연구는 신흥시장 지수와 글로벌시장 지수를 이용하여 생애주기 및 경기순환 주기를 고려한 장기 적립식 투자모형(가칭 $\mathrm{BLCF}$ ) 개발을 목적으로 한다. 먼저 연령대에 따라 불확실성에 대한 수용률이 다르다는 점에 착안하여 신흥시장에서 글로벌시장으로 비중을 서서히 늘리도록 모형을 설계하였다. 다음으로 시장 상황을 고려하여 수익률을 확보하고자 하였다. 경기변동주기를 고려하여 호황기에는 성장성이 높은 신흥시장으로, 침체기에는 안정성이 높은 글로벌시장으로 투자 비중을 변화시킴으로써 모형의 성과를 개선하고자 하였다. 또한 금, 미 국채 등 경기역행적 자산을 추가하여 위험 상황에서 효과적으로 위기를 회피하고자 하였다. 분석결과, 경기변동주기를 고려한 모형은 각각 약 $9.06 ~ 10.11 \%$, 0.524 0.571의 연수익률과 샤프지수를 가지며 동 기간 단일지수 투자보다 더 높은 성과를 보여주었다. 경기역행적 자산을 추가로 고려한 경우 약 $9.68 \%$ 13.95\%의 연수익률과 $0.613 \sim 0.849$ 의 샤프지수를 보이며, 기존 모형보다 수익률 및 안정성에서 추가적인 개선이 나타났다. 본 연구는 향후 TDF 설계방식 및 한국의 퇴직연금 디폴트옵션 설정에 있어 실무적, 정책적 시사점을 제시한다.
\end{abstract}

핵심 단어 : TDF, BLCF, 경기변동주기, 경기역행성자산, 디폴트옵션

JEL 분류기호: G1

* 본 연구는 2018년 한국증권학회-미래에셋자산운용 신진학자 연구지원사업의 연구지원을 받아 수행되었습니다.

** 연락담당 저자. 주소: 서울특별시 성동구 왕십리로 222, 경영대학, 04763; E-mail: khbae@hanyang.ac.kr; Tel: 02-2220-1044; Fax: 02-2220-1169. 


\section{1. 서론}

2017년 대한민국의 평균기대수명은 82.7세로 44년 간 평균수명이 약 20.8세 증가하였으며, 2018년 고령인구는 전체인구의 약 $14.3 \%$ 로 대한민국은 고령사회로 진입하였다(통계청, 2018). 이렇듯 대한민국이 고령사회로 접어들면서 노후대비에 대한 중요성이 대두되고 있다. 국민들의 수명이 길어진 만큼 이전보다 더 많은 액수를 보장해줄 수 있는 연금이 필요해진 것이다. 그러나 국민들에게 가장 기본적인 노후대비 수단이었던 국민연금이 고갈에 대한 우려로 인하여 신뢰도가 악화되고 있다. 이에 따라 투자자들은 국민연금이 아닌 다른 투자 대상을 찾고 있으며 이에 대한 대안으로 Target Date Fund(TDF)가 떠오르고 있다(Jang, 2018). 게다가 2018년 9월 $\mathrm{TDF}$ 의 비보장성자산 비율이 $40 \%$ 에서 $80 \%$ 로 완화되면서 $\mathrm{TDF}$ 시장은 더욱 탄력을 받게 되었다(Appell, 2018). 그러나 Spitzer and Singh(2008)에 따르면 생애주기만을 고려한 TDF는 시장상황에 대한 고려가 없어 유효한 투자전략이 되기 어렵다. 이에 본 연구에서는 경기변동 주기, 글로벌 리스크를 고려한 TDF를 만들어 유효한 연금펀드 투자전략을 구상한다.

$\mathrm{TDF}$ 는 투자자의 생애주기에 따라 위험수용률이 변화한다는 모딜리아니의 생애주기 가설을 수용하여 은퇴시점을 Target Date로 설정, 시간이 흐름에 따라 포트폴리오 리스크를 조절해주는 펀드이다. 전술한 이유로 TDF에 대한 국내 수요는 크게 증가하여 2017년 시장규모가 1조 원에 달하였으며 미국에서는 이미 2000년 대 중반부터 급속도로 성장하여 시장규모가 1,000 조 원을 넘어섰다(Byun, 2018). 그러나 TDF는 시장 리스크에 온전히 노출된다는 문제점이 있다. 이러한 문제점을 회피하기 위해서는 시장에서 위기상황이 발생하는 때를 미리 파악하여 경기하락국면일 때는 상대적으로 안전한 자산으로 비중을 이전할 필요성이 있다. 이에 본 연구팀은 시장지수를 이용하여 미래의 경기국면을 예측하고 이를 모형 내에서 경기국면변수로 사용한다.

본 연구에서는 $\mathrm{TDF}$ 의 약점으로 꼽히는 수익률의 문제를 해결하고자 투자 대상을 시장지수로 선정하고 상대적인 위험성에 따라 비중을 조정한다. 그러나 투자 대상인 두 자산이 모두 시장지수일 경우 금융의 전염성으로 인하여 전 세계적으로 위기가 발생하였을 때 두 자산 모두 수익률이 급락할 수 있다는 문제점이 있다. 이를 회피하기 위해서 본 연구에서는 모형에 금, 미 국채, 달러화와 같은 시장과 반대방향으로 변동하는 자산을 이용하여 문제를 해결하고자 하였다.

이러한 이유로 본 연구팀은 생애주기만을 고려한 투자모형(BLCF-Li), 생애주기와 경기변동 주기를 모두 고려한 모형(BLCF), 두 주기를 모두 고려하면서 위기상황에 대한 회피까지 고려한 모형 $(\mathrm{BLCF}-\mathrm{H})$ 을 차례로 백데이팅 기법을 이용하여 분석 및 검증하였다. 시뮬레이션 결과 기존의 $\mathrm{TDF}$ 와 같이 생애주기만을 고려하는 $\mathrm{BLCF}-\mathrm{Li}$ 모형은 개별 시장지수들과 비교하여 성과의 뚜렷한 개선이 나타나지 않았다. 그러나 BLCF 모형과 BLCF-H 모형의 경우, 개별 시장지수들과 비교하여 수익률과 샤프지수 모두에서 더 높은 성과를 보였다. 구체적으로 투자시작 시점을 1975.01.31부터 1988.05.31까지 매월 말일로 두고 30년간 투자하였을 때의 161 개의 투자결과를 사용하여 비교하면, 환헤지 상황에서의 MSCI World 지수 수익률은 연평균 약 $7.37 \%$ 인 반면, BLCF 모형은 연평균 약 9.92\%의 수익률이 나타난다. BLCF-H(Gold), BLCF-H (Bond), $\mathrm{BLCF}-\mathrm{H}(\mathrm{Ex})$ 모형은 각각 약 9.68\%, $11.13 \%, 13.95 \%$ 의 연평균 수익률이 나타난다. 


\section{2. 문헌 연구}

$\mathrm{TDF}$ 는 일반적으로 연금펀드에서 활용되는 투자전략이며, 생애주기를 고려하여 시간이 지남에 따라 위험자산에서 안전자산으로 비중을 이전하는 방식을 사용한다는 점에서 라이프사이클 펀드라고도 한다. TDF가 연금펀드로 사용되는 가장 주요한 근거는 투자자의 리스크 허용한계가 동태적으로 변화한다는 점이다. 이는 가구주의 연령과 투자자산의 선택 간의 상관관계를 분석함으로써 알 수 있다. Yuh and Joung(2004)의 연구에 의하면, 가구주의 연령과 가계의 주식투자가능성은 음의 상관관계에 있는 반면. Jeong(2008)에 따르면 가구주의 연령과 은행예금 간에는 양의 상관관계가 존재한다.

그러나 단순히 생애주기만을 고려한 전통적인 $\mathrm{TDF}$ 의 경우, 투자성과가 낮아 유효한 투자전략 이라고 보기 어려우며, 최저요구수익률에 도달하지 못할 수 있다는 위험을 가지고 있기 때문에 개선되어야 할 필요가 있다(Arnott et al., 2014; Basu et al., 2011; Booth and Chang, 2011; Branch and Qui, 2011; Forsyth et al., 2017; Pang and Warshawsky, 2009; Pang and Warshawsky, 2011; Spitzer and Singh, 2008, 2011; Yoon, 2010).

이러한 TDF의 투자성과를 개선할 방법론으로 동태적 투자전략의 도입을 고려할 수 있다. Booth and Chang(2011)은 미국시장에서 TDF의 2008년 성과를 분석하여 시장에 반응할 수 있는 동태적 전략의 필요성을 환기하였다. 마찬가지로 Arnott et al.(2014)도 미국시장에서 전통적 글라이드패스 투자의 성과를 분석하여 동적인 투자방식의 필요성을 주장하였다. 이에 Yoon(2010)과 Basu et al.(2011)은 미국시장에서 비중의 동태적 변화를 통하여 TDF 수익률의 개선을 이끌어냈다. Lee(2016) 역시 한국시장에서 경기국면을 고려한 동태적 TDF를 통하여 수익률의 개선과 리스크의 감소를 이끌어 내었고, 특히 하방위험을 뚜렷하게 감소시켰다. 다른 개선방안으로 시장상황을 고려하는 것뿐만 아니라 국내주식과 해외주식을 혼합한 포트폴리오를 사용함으로써 $\mathrm{TDF}$ 를 개선할 수 있다는 견해가 있다(Kim, 2017).

다만, 본 연구에서와 같이 주가지수만을 이용하여 포트폴리오를 구성할 경우, 글로벌 리스크를 회피하기 어렵다. Kim and Lee(2012)의 연구에 따르면 글로벌 금융위기 이후 금융의 동조화 현상이 강화되면서 금융 전염효과가 심화되었으며, 이러한 점에서 글로벌 리스크에 대한 고려는 필수적인 요소가 되었다. 글로벌 리스크를 회피할 때 사용되는 자산으로 보통 경기변동과 반대로 움직이는 자산이 사용된다. 이러한 자산으로는 전통적으로 금 및 채권이 있으며 수차례의 연구로 인하여 유효성이 증명되었다(Ciner et al., 2012; Bredin et al., 2015). 또한 최근의 연구에 의하면 한국과 미국의 주식시장의 경우 금을 활용한 리스크 헤지는 효과적인 것으로 나타났다(Choi, 2018).

\section{Data}

본 연구는 1975.01.31 2018.05.31 기간 동안의 KOSPI, MSCI World 지수, 원/달러 환율, 금, 미국 10년 채권 데이터를 사용한다. 데이터는 FnGuide(http: //www.fnguide.com)에서 수집하였다. 환율의 영향을 고려하기 위하여 환율 리스크에 노출시킬 경우, 결과값 뒤에 "Ex"를 추가하여 나타낸다. 
한국증권학회지 제48권 6호 (2019)

<표 1>에서 KOSPI의 경우, 수익률의 표준편차가 다른 자산들과 비교하여 가장 크고, 평균수익률 역시 가장 높다는 점에서, 성장성과 변동성이 높은 신흥시장을 대표하기에 충분하다고 할 수 있다. 반면 MSCI World 지수의 경우, KOSPI 지수에 비해 낮은 표준편차를 가진다는 점에서 상대적으로 안정적인 시장이라고 할 수 있다.

\section{〈표 1〉 투자자산의 요약 통계량}

1975.01.31 2018.05.31 기간 동안의 KOSPI, MSCI World 지수, 원/달러 환율, 금, 미국 10년 채권 데이터의 월간 수익률 요약 통계량이다. KP는 KOSPI 지수, World는 MSCI World 지수를 나타내며, $\mathrm{Ex}$, gold, bond는 각각 원/달러 환율, 금의 온스 당 달러 가격(미국 기준), 미국 10 년 채권 데이터를 수익률로 변환하여 사용하였다. KOSPI와 MSCI World 지수는 각각 신흥시장(Emerging Market, 이하 $\mathrm{EM})$ 과 글로벌 시장 (Global Market, 이하 GM)을 상징하므로, 각각 $\mathrm{EM}, \mathrm{GM}$ 으로 나타내었다.

\begin{tabular}{lcccrc}
\hline & KOSPI(EM) & World(GM) & Ex & gold & bond \\
\hline count & 520 & 520 & 520 & 520 & 520 \\
mean & $0.93 \%$ & $0.70 \%$ & $0.20 \%$ & $0.49 \%$ & $0.51 \%$ \\
std & 0.0729 & 0.0414 & 0.0292 & 0.0478 & 0.0025 \\
min & $-27.25 \%$ & $-19.05 \%$ & $-15.93 \%$ & $-16.76 \%$ & $0.12 \%$ \\
$25 \%$ & $-2.88 \%$ & $-1.75 \%$ & $-0.55 \%$ & $-1.83 \%$ & $0.32 \%$ \\
$50 \%$ & $0.58 \%$ & $0.98 \%$ & $0.00 \%$ & $0.03 \%$ & $0.50 \%$ \\
$75 \%$ & $4.24 \%$ & $3.15 \%$ & $0.75 \%$ & $2.58 \%$ & $0.67 \%$ \\
$\max$ & $50.77 \%$ & $11.57 \%$ & $21.60 \%$ & $45.49 \%$ & $1.19 \%$ \\
\hline
\end{tabular}

\section{BLCF-Linear Model(BLCF-Li)}

가장 먼저 생애주기 가설에 따른 투자의 유효성을 검증하기 위하여 생애주기만을 고려한 투자를 진행한다. 생애주기에 따라 투자자의 위험수용률이 달라진다는 점에 착안하여 투자 초반에는 수익성과 변동성이 모두 높은 신흥시장 지수에 투자를 진행하다가 시간의 흐름에 따라 변동성이 상대적으로 낮은 글로벌시장 지수로 투자대상을 전환하여 투자를 진 행한다.

\subsection{BLCF-Linear 모형(이하 BLCF-Li) 설계}

$\mathrm{BLCF}-\mathrm{Li}$ 모형은 총 투자기간동안 매월 동일금액을 적립하는 적립식 펀드 형태를 가지며, 매월 말에 리밸런싱된다. 투자대상은 KOSPI를 신흥시장지수로(EM: KOSPI) MSCI World 지수를 글로벌시장 지수로(GM: MSCI World Index) 사용한다. 글로벌시장 지수의 경우 해외지수에 해당하므로 환율의 영향을 받는 경우와 받지 않는 경우로 나누어 투자결과를 분석하며 환율에 노출된 지수의 경우 지수에 $\mathrm{Ex}$ 를 붙여 나타낸다. 수집된 데이터는 1975.01.31 2018.05.31 매월 종가로 표시한 KOSPI지수와 MSCI World 지수이다.

먼저 총 투자기간을 전환기간(P1)과 전환 후 투자기간(P2)으로 나눈다. 초기에는 신흥시장 지수에 전액 투자하되, 전환기간 동안 글로벌시장 지수로 투자비중을 이전한다. 전환기간 동안의 투자비중 이전은 동일비중 이전을 원칙으로 한다. 전환 후 투자기간 동안에는 글로벌시장 지수에 전액 투자한다. 
An Investment Strategy Based on Life and Business Cycles

본 연구에서는 전환기간과 전환 후 보유기간의 선택지를 120,180 240개월로 한정하며, 따라서 가능한 총 투자기간을 20 40년으로 설정한다. 또한 투자금액은 매월 10단위로 가정한다.

시간(t)의 변화에 따른 투자비중 $(\mathrm{W})$ 변화는 다음과 같이 진행된다.

$$
\begin{aligned}
& t=0, \quad\left(W_{E M}, W_{G M}\right)=(1,0) \\
& 0<t \leq P_{1}, \quad\left(W_{E M}, W_{G M}\right)=\left(1-\frac{t}{P_{1}}, 0+\frac{t}{P_{1}}\right) \\
& P_{1}<t \leq P_{2}, \quad\left(W_{E M}, W_{G M}\right)=(0,1)
\end{aligned}
$$

\section{2 투자결과}

투자 결과를 보면 먼저 환율의 반영 유무에 따라 수익률에 약 $1 \sim 2 \% \mathrm{p}$ 의 차이가 발생함을 알 수 있다. 이는 투자기간동안 환율이 상승하였고, 이러한 요인이 데이터에 반영된 결과라고

〈표 2〉 BLCF-Li 모형을 포함한 각각의 지수에 대한 투자수익률 및 샤프지수의 평균치

1975.01.31 2018.05.31 기간 동안 각각의 지수에 대한 투자수익률 및 샤프지수의 평균치 자료를 전환기간 (P1)과 전환 후 투자기간(P2)에 따라 나열해놓은 데이터이다. 전환기간이란 시간에 따라 투자비중을 신흥시장에서 글로벌시장으로 전환하는 기간을 의미하며, 초기에는 신흥시장 지수에 전액 투자하되, 전환기간 동안 글로벌시장 지수로 투자비중을 이전한다. 전환기간 동안의 투자비중 이전은 동일비중 이전을 원칙으로 한다. 전환 후 투자기간은 글로벌시장 지수로 전액 투자한 상태로 투자를 유지하는 기간을 의미한다. 투자시작시점에 따라 투자결과가 다르게 도출될 수 있다는 점을 감안하여 총 투자기간이 20년, 25년, 30년, 35년, 40년일 때 각각 1975.01.31 1998.05.31, 1975.01.31 1993.05.31, 1975.01.31 1988.05.31, 1975.01.31 1983.05.31, 1975.01.31 1978.05.31를 투자시작시점으로 하여 결과를 도출하고

\begin{tabular}{|c|c|c|c|c|c|}
\hline P1_P2 & $\mathrm{BLCF}-\mathrm{Li}$ & BLCF-Li Ex & World & World_Ex & KOSPI \\
\hline \multirow[t]{2}{*}{ 10_10 } & $7.38 \%$ & $8.90 \%$ & $7.45 \%$ & $9.86 \%$ & $7.30 \%$ \\
\hline & $(0.466)$ & $(0.531)$ & $(0.514)$ & $(0.617)$ & $(0.255)$ \\
\hline \multirow[t]{2}{*}{ 10_15 } & $7.60 \%$ & $9.23 \%$ & $7.32 \%$ & $9.59 \%$ & $7.59 \%$ \\
\hline & $(0.491)$ & $(0.562)$ & $(0.501)$ & $(0.601)$ & $(0.256)$ \\
\hline \multirow[t]{2}{*}{ 15_10 } & $7.69 \%$ & $9.10 \%$ & $7.32 \%$ & $9.59 \%$ & $7.59 \%$ \\
\hline & $(0.475)$ & (0.536) & $(0.501)$ & $(0.601)$ & $(0.256)$ \\
\hline \multirow[t]{2}{*}{ 10_20 } & $8.19 \%$ & $9.65 \%$ & $7.44 \%$ & $9.35 \%$ & $8.75 \%$ \\
\hline & $(0.531)$ & $(0.605)$ & $(0.504)$ & $(0.595)$ & $(0.306)$ \\
\hline \multirow[t]{2}{*}{ 15_15 } & $8.34 \%$ & $9.63 \%$ & $7.44 \%$ & $9.35 \%$ & $8.75 \%$ \\
\hline & $(0.525)$ & $(0.591)$ & $(0.504)$ & $(0.595)$ & $(0.306)$ \\
\hline \multirow[t]{2}{*}{ 20_10 } & $8.30 \%$ & $9.38 \%$ & $7.44 \%$ & $9.35 \%$ & $8.75 \%$ \\
\hline & $(0.496)$ & $(0.557)$ & $(0.504)$ & (0.595) & $(0.306)$ \\
\hline \multirow[t]{2}{*}{ 15_20 } & $7.99 \%$ & $9.34 \%$ & $7.44 \%$ & $9.61 \%$ & $8.56 \%$ \\
\hline & $(0.517)$ & $(0.602)$ & $(0.498)$ & (0.623) & (0.313) \\
\hline \multirow[t]{2}{*}{ 20_15 } & $8.00 \%$ & $9.17 \%$ & $7.44 \%$ & $9.61 \%$ & $8.56 \%$ \\
\hline & (0.499) & (0.579) & $(0.498)$ & $(0.623)$ & $(0.313)$ \\
\hline \multirow[t]{2}{*}{ 20_20 } & $7.86 \%$ & $9.17 \%$ & $7.38 \%$ & $9.68 \%$ & $7.95 \%$ \\
\hline & $(0.521)$ & $(0.611)$ & $(0.506)$ & (0.638) & $(0.305)$ \\
\hline
\end{tabular}
이 결과들의 평균치를 기록하였다. 투자수익률의 경우 수익률을 연율화하였다. 괄호 밖의 데이터는 연 평균 투자수익률, 괄호 안의 데이터는 샤프지수를 나타낸다. 
한국증권학회지 제48권 6호 (2019)

볼 수 있다. BLCF-Li 모형과 시장지수 간의 성과를 비교해보면 투자기간에 따라 우열이 갈리는 등 $\mathrm{BLCF}-\mathrm{Li}$ 모형이 절대우위에 있다고 보기 어렵기 때문에 수익률의 개선이 발생하였다고 보기 어려우며, 이러한 점에서 초과수익률을 확보하지 못하고 있다고 볼 수 있다.

다음으로 샤프지수를 비교해보면 BLCF-Li 모형은 환노출이 존재할 경우 $0.531 ~ 0.611$, 존재하지 않을 경우 0.466 0.531의 샤프지수를 가지며 0.255 0.313의 샤프지수를 보이는 KOSPI 지수에 대한 단일지수투자와 비교하여 샤프지수의 명백한 개선이 발생하였다. 이를 통해 신흥국 지수에 대한 단일투자보다 신흥국 지수와 글로벌 지수를 이용하여 포트폴리오를 구성하는 것이 변동성을 줄이는 데에 효과적임을 알 수 있다. 그러나 환헤지를 가정하였을 때는 0.498 0.514, 환노출을 가정하였을 때는 0.595 0.638의 샤프지수를 보이는 MSCI World 지수에 대한 단일지수투자와 비교하였을 때는 샤프지수가 충분히 개선되지 못하였음을 알 수 있다. 수익률의 측면에서 BLCF-Li 모형과 MSCI World 지수 간의 차이가 적었다는 것을 감안하였을 때 $\mathrm{BLCF}-\mathrm{Li}$ 모형이 변동성을 충분히 감소시키지 못한 것을 알 수 있다.

$\mathrm{BLCF}-\mathrm{Li}$ 모형의 기간별 수익률을 비교하면, 30년 동안의 투자기간을 가질 때, 연 8.19\% 8.34\%로 평균 수익률이 가장 높았고, 샤프지수 역시 0.496 0.531로 다른 투자시기들보다 높은 수치를 보이고 있다. 구체적으로 환노출의 상황에서 투자기간이 $(\mathrm{P} 1, \mathrm{P} 2)=(10,20)$ 일 때, 수익률과 샤프지수가 각각 연 8.30\%와 0.525로 매우 높은 수치를 보임을 알 수 있다.

\section{BLCF Model}

생애주기만을 고려한 모형에 더하여 초과 수익을 달성하기 위하여 경기변동주기를 추가로 고려하였다. 금융 세계화로 인해 신흥시장 지수와 글로벌 시장 지수가 유사한 경기순환 흐름을 보이는 경향이 생겼다는 점, 글로벌 시장에 비해 신흥시장의 변동성이 상대적으로 높다는 점을 근거로 호황기에는 신흥시장의 투자 비중을 증가시켜 수익률을 높이고, 침체기에는 글로벌시장의 투자 비중을 증가시켜 변동성을 낮추고자 하였다.

\section{1 경기변동 실증분석}

$\mathrm{BLCF}$ 모형의 생성에 앞서 경기변동주기에 따른 투자의 근거에 대한 실증분석을 실시하였다.

$\mathrm{BLCF}$ 모형은 금융 세계화가 진행됨에 따라 신흥시장과 글로벌 시장이 유사한 경기변동을 보인다는 것을 가정한다. <표 3>을 보면 KOSPI와 MSCI World 지수는 지수 수익률 간 상관 관계가 0.4332 로 높은 상관관계를 보인다. 이를 통해 두 지수가 실제로 유사한 경기순환 흐름을 가진다는 것을 확인할 수 있다.

또한 BLCF 모형은 신흥시장이 글로벌시장에 비해 더 높은 변동성을 가지고 있다는 것을 전제하고 있다. 본 연구에서 신흥시장지수로 설정된 KOSPI의 변동성은 글로벌시장을 대표하는 MSCI World 지수의 변동성보다 크다. 따라서, KOSPI 지수와 MSCI World 지수는 강한 양의 상관관계를 보이며 동조성을 보이고 있고, 신흥시장이 글로벌시장에 비해 더 높은 변동성을 가지고 있으므로, 경기변동 주기를 고려함으로써 투자전략을 개선할 수 있다. 
An Investment Strategy Based on Life and Business Cycles

〈표 3〉KOSPI와 World 지수의 상관관계 및 변동성

1975.01.31 2018.05.31 기간 동안의 KOSPI와 MSCI World 지수 간의 상관관계 및 변동성이다. KP 는 KOSPI, MSCI World는 World로 나타내었으며, 원/달러 환율의 영향을 MSCI World 지수에 포함시킬 경우 $(+\mathrm{Ex})$ 로 나타내었다. 지수간 상관관계 분석에는 Index를, 수익률 간 상관관계 분석에는 Return을 사용하여 나타내었다.

\begin{tabular}{lcclc}
\hline \multicolumn{1}{c}{ Type } & Correlation & & \multicolumn{1}{c}{ Type } & Volatility \\
\cline { 1 - 2 } KP-World Index & 0.9007 & & KP Return & 0.2513 \\
KP-World Return & 0.4332 & & World Return & 0.1540 \\
KP-World(+Ex) Return & 0.2511 & & World(+Ex) Return & 0.1298 \\
\hline
\end{tabular}

\subsection{BLCF 모형 설계}

금융 세계화로 인하여 신흥시장 지수와 글로벌 시장 지수가 유사한 경기순환 흐름을 보이고, 신흥시장 지수의 변동성이 글로벌 시장 지수와 비교하여 더 높다면, 경기변동에 따라 호황일 경우 신흥시장의 지수 수익률이 글로벌시장보다 더 가파르게 상승할 것이다. 반면, 불황일 경우 신흥시장 지수 수익률이 글로벌시장보다 더 가파르게 하락할 것이다. 경기순환 흐름은 연속적이며, 따라서 신흥시장 지수와 글로벌시장 지수와의 수익률 갭을 통해 경기국면을 읽을 수 있다. 실제로 금융위기 당시인 2008년 10월 한 달 동안 KOSPI 지수는 약 $23 \%$ 하락하였으나, S\&P 500 지수의 하락폭은 약 7\%이었으며, 반대로 회복기인 2009년 3, 4월동안 KOSPI 지수는 각각 약 $13 \%, 14 \%$ 상승한 반면, S\&P 500지수는 약 $9 \%, 5 \%$ 상승하였다.

이러한 아이디어에 착안하여 신흥시장 지수와 글로벌시장 지수와의 수익률 갭을 이용하여 경기국면 변수 $(\mathrm{Gap})$ 를 구성한다. 일정기간동안 신흥시장 지수의 누적수익률이 글로벌시장 누적수익률에 비해 $1 \% \mathrm{p}$ 높을 때마다 신흥시장으로 투자비중을 $1 \% \mathrm{p}^{1)}$ 이전한다. 반대로 글로벌 시장 지수의 누적수익률이 신흥시장에 비해 $1 \% \mathrm{p}$ 높을 때마다 글로벌시장으로 투자비중을 $1 \% \mathrm{p}$ 이전한다. 이 방식은 투자기간 전체에 걸쳐 진행한다. 비중 조정에서 공매는 수반하지 않는다. 따라서 경기국면변수에 의해 신흥시장 혹은 글로벌시장 비중이 0 미만으로 떨어질 경우에는 비중을 0 으로, 1 을 초과할 경우에는 비중을 1 로 고정한다. 비중 이외의 모든 조건은 $\mathrm{BLCF}-\mathrm{Li}$ 모형과 동일하게 적용하였다. 경기국면변수의 시차에 대해서는 다음 장에서 논의한다.

경기국면변수

$$
\operatorname{Gap}_{t}=\prod_{i=1}^{n} \operatorname{Ret}_{E M, t-i}-\prod_{i=1}^{n} \operatorname{Ret}_{G M, t-i}
$$

1) 경기 국면에 따라 투자비중을 조정하는 경우, 경기국면변수의 경기예측력이 높을수록 투자비중을 크게 변화시킬 때, 수익률이 증가한다(<Appendix $\Pi>$ ). 그러나 이는 동시에 월간 투자비중의 변화율을 크게 가져간다는 의미이기도 하다. 일반적으로 연금펀드는 자금규모가 커서 분석되는 것보다 실제 거래비용이 훨씬 크게 작용할 수 있으며, 시장을 왜곡시킬 수 있다. 이러한 점을 고려하여 경기국면 변수에 따른 투자비중 변화율을 $1 \%$ 로 고정, 투자비중의 변화를 보수적으로 설정하였다. 
시간(t)의 변화에 따른 투자비중(W) 변화는 다음과 같이 진행된다.

$$
\begin{gathered}
t=0, \quad\left(W_{E M}, W_{G M}\right)=(1,0) \\
0<t \leq P_{1}, \quad\left(W_{E M}, W_{G M}\right)=\left(1-\frac{t}{P_{1}}+\operatorname{Gap}_{t}, 0+\frac{t}{P_{1}}-G a p_{t}\right) \\
P_{1}<t \leq P_{2}, \quad\left(W_{E M}, W_{G M}\right)=\left(G_{a}, 1-G a p_{t}\right) \\
W_{E M}\left(\text { or } W_{G M}\right)<0 \text { 이면, } W_{E M}\left(\text { or } W_{G M}\right)=0, \\
W_{E M}\left(\text { or } W_{G M}\right)>1 \text { 이면, } W_{E M}\left(\text { or } W_{G M}\right)=1
\end{gathered}
$$

단, $W_{E M}\left(\right.$ or $\left.W_{G M}\right)<0$ 이면, $W_{E M}\left(\right.$ or $\left.W_{G M}\right)=0$,

\subsection{BLCF 모형 경기국면변수의 최적시차 결정}

$\mathrm{BLCF}$ 모형에서 경기국면변수는 글로벌시장과 신홍시장의 수익률 갭을 통해 만들어진다. 본 장에서는 경기국면을 파악하는데 있어서, 수익률 갭의 최적시차에 대해 분석하였다.

<표 4>에서 투자기간에 관계없이 9 10개월 동안의 수익률 갭을 기준으로 투자하였을 때, 수익률은 연 $11.68 \%$ 12.90\%의 수치를 샤프지수는 $0.658 \sim 0.719$ 의 수치를 보이며 극대화됨을 알 수 있다. 이는 키친순환 주기(단기 경기변동 주기, 40 개월 주기)의 경기국면이 약 10 개월마다 전환된다는 이론적 배경과 일치한다는 점에서도 그 근거를 얻을 수 있다(Kitchin, 1923).

〈표 4〉 투자기간 및 모멘텀 기간에 따른 BLCF Ex의 수익률 및 샤프지수

1975.01.31 2018.05.31 기간 동안 투자기간 및 모멘텀 기간에 따른 BLCF Ex의 수익률 및 샤프지수을 도출한 데이터이다. $\mathrm{BLCF} \mathrm{Ex}$ 란 환노출의 가정 하에서 $\mathrm{BLCF}$ 모델의 투자전략을 진행한 모델을 의미한다. 환노출의 가정이므로 MSCI World 지수의 수익률은 지수변화율에 환율 변화율을 더하여 산출하였다. $\mathrm{BLCF}$ 모델의 투자전략은 두 가지로 구분된다. 첫 번째는 시간에 따라 신흥시장에서 글로벌 시장 지수로 투자비중을 이전하는 전략이다. 이 전략은 전환기간(P1)과 전환 후 투자기간(P2)에 의하여 투자비중의 이전속도가 변화한다는 특징이 있다. 전환기간이란 시간에 따라 투자비중을 신흥시장에서 글로벌시장으로 전환하는 기간을 의미하며, 초기에는 신흥시장 지수에 전액 투자하되, 전환기간 동안 글로벌시장 지수로 투자비중을 동일비중 이전한다. 모멘텀에 변화가 없는 한, 전환기간의 종료시점에는 글로벌시장 지수로 투자비중이 전액 투자된다. 전환 후 투자기간은 모멘텀에 변화가 없는 한, 글로벌시장 지수로 전액 투자한 상태로 투자를 유지하는 기간을 의미한다. <표 4>의 세로축은 전환기간 (P1)과 전환 후 투자기간(P2)을 나타낸다. BLCF 모델의 두 번째 전략은 수익률 모멘텀에 따라 투자비중을 이전하는 방식이다. 이 전략은 신흥시장이 글로벌 시장보다 $\mathrm{n}$ 개월 동안의 누적수익률이 $1 \% \mathrm{p}$ 증가할 때마다 신흥시장으로 비중을 $1 \% \mathrm{p}$ 이전하며, 반대로 글로벌시장의 $\mathrm{n}$ 개월 누적수익률이 $1 \% \mathrm{p}$ 증가할 때마다 글로벌시장으로 비중을 $1 \% \mathrm{p}$ 이전한다. 투자시작시점에 따라 투자결과가 다르게 도출될 수 있다는 점을 감안하여 총 투자기간이 20년, 25년, 30년, 35년, 40년일 때 각각 1975.01.31 1998.05.31, 1975.01.31 1993.05.31, 1975.01.31 1988.05.31,

\begin{tabular}{|c|c|c|c|c|c|c|c|c|c|c|c|c|}
\hline & 1 & 2 & 3 & 4 & 5 & 6 & 7 & 8 & $9^{*}$ & $10^{*}$ & 11 & 12 \\
\hline 10_10 & $\begin{array}{r}9.37 \% \\
(0.554)\end{array}$ & $\begin{array}{r}9.77 \% \\
(0.566)\end{array}$ & $\begin{array}{c}10.48 \% \\
(0.599)\end{array}$ & $\begin{array}{c}10.88 \% \\
(0.617)\end{array}$ & $\begin{array}{r}11.57 \% \\
(0.646)\end{array}$ & $\begin{array}{r}12.06 \% \\
(0.660)\end{array}$ & $\begin{array}{c}12.43 \% \\
(0.683)\end{array}$ & $\begin{array}{r}12.44 \% \\
(0.675)\end{array}$ & $\begin{array}{r}12.79 \% \\
(0.692)\end{array}$ & $\begin{array}{c}12.79 \% \\
(0.689)\end{array}$ & $\begin{array}{c}12.57 \% \\
(0.675)\end{array}$ & $\begin{array}{c}12.67 \% \\
(0.677)\end{array}$ \\
\hline 15_10 & $\begin{array}{c}9.47 \% \\
(0.551)\end{array}$ & $\begin{array}{r}9.95 \% \\
(0.566)\end{array}$ & $\begin{array}{c}10.63 \% \\
(0.595)\end{array}$ & $\begin{array}{c}10.97 \% \\
(0.608)\end{array}$ & $\begin{array}{c}11.59 \% \\
(0.630)\end{array}$ & $\begin{array}{r}11.99 \% \\
(0.640)\end{array}$ & $\begin{array}{c}12.34 \% \\
(0.661)\end{array}$ & $\begin{array}{r}12.27 \% \\
(0.647)\end{array}$ & $\begin{array}{c}12.71 \% \\
(0.669)\end{array}$ & $\begin{array}{c}12.57 \% \\
(0.658)\end{array}$ & $\begin{array}{r}12.37 \% \\
(0.646)\end{array}$ & $\begin{array}{r}12.36 \% \\
(0.645)\end{array}$ \\
\hline
\end{tabular}
1975.01.31 1983.05.31, 1975.01.31 1978.05.31를 투자시작시점으로 하여 결과를 도출하고 이 결과들의 평균치를 기록하였다. 투자수익률의 경우 수익률을 연율화 하였다. <표 $4>$ 의 가로축은 모멘텀 산출 기간(n, 단위 : 월)을 나타낸다. 괄호 밖의 데이터는 연 평균 투자수익률, 괄호 안의 데이터는 샤프지수를 나타낸다. 
An Investment Strategy Based on Life and Business Cycles

〈표 4〉 투자기간 및 모멘텀 기간에 따른 BLCF Ex의 수익률 및 샤프지수(계속)

\begin{tabular}{|c|c|c|c|c|c|c|c|c|c|c|c|c|}
\hline & 1 & 2 & 3 & 4 & 5 & 6 & 7 & 8 & $9^{*}$ & $10^{*}$ & 11 & 12 \\
\hline \multirow[t]{2}{*}{ 10_15 } & $9.52 \%$ & $10.00 \%$ & $10.61 \%$ & $10.95 \%$ & $54 \%$ & $11.82 \%$ & $15 \%$ & $12.28 \%$ & $12.56 \%$ & $12.49 \%$ & $12.19 \%$ & $12.32 \%$ \\
\hline & $(0.576)$ & $(0.592)$ & $(0.622)$ & $(0.637)$ & $(0.659)$ & $(0.659)$ & $.680)$ & $.676)$ & $(0.689)$ & $(0.681)$ & $(0.664)$ & $(0.666)$ \\
\hline \multirow[t]{2}{*}{ 10_20 } & $9.78 \%$ & $10.22 \%$ & $10.79 \%$ & $11.15 \%$ & $11.68 \%$ & $11.89 \%$ & $12.20 \%$ & $12.43 \%$ & $12.66 \%$ & $12.70 \%$ & $12.34 \%$ & $12.60 \%$ \\
\hline & $(0.610)$ & (0.625) & (0.655) & $(0.672)$ & $(0.691)$ & (0.688) & $(0.707)$ & $(0.709)$ & (0.719) & $(0.717)$ & (0.697) & $(0.704)$ \\
\hline \multirow[t]{2}{*}{ 15_15 } & $9.83 \%$ & $10.31 \%$ & $10.94 \%$ & $11.27 \%$ & $11.79 \%$ & $12.06 \%$ & $12.42 \%$ & $12.49 \%$ & $12.87 \%$ & $12.83 \%$ & $12.51 \%$ & $12.62 \%$ \\
\hline & $(0.595)$ & $(0.611)$ & $(0.641)$ & $(0.653)$ & $(0.671)$ & (0.673) & $(0.694)$ & $(0.688)$ & $(0.707)$ & (0.699) & $(0.682)$ & $(0.685)$ \\
\hline \multirow[t]{2}{*}{ 20_10 } & $9.72 \%$ & $10.18 \%$ & $10.88 \%$ & $11.21 \%$ & $11.77 \%$ & $12.12 \%$ & $12.53 \%$ & $12.39 \%$ & $12.90 \%$ & $12.76 \%$ & $12.57 \%$ & $12.57 \%$ \\
\hline & $(0.566)$ & $(0.580)$ & $(0.610)$ & $(0.621)$ & $(0.640)$ & $(0.649)$ & $(0.674)$ & $(0.658)$ & $(0.685)$ & $(0.673)$ & $(0.663)$ & $(0.664)$ \\
\hline \multirow[t]{2}{*}{ 15_20 } & $9.42 \%$ & $9.79 \%$ & $10.31 \%$ & $10.70 \%$ & $11.16 \%$ & $11.37 \%$ & $11.72 \%$ & $11.92 \%$ & $12.24 \%$ & $12.30 \%$ & $11.92 \%$ & $12.22 \%$ \\
\hline & $(0.602)$ & (0.613) & $(0.640)$ & $(0.657)$ & $(0.673)$ & $(0.671)$ & $(0.692)$ & $(0.693)$ & $(0.709)$ & $(0.706)$ & $(0.684)$ & $(0.696)$ \\
\hline \multirow[t]{2}{*}{ 20_15 } & $9.37 \%$ & $9.75 \%$ & $10.36 \%$ & $10.73 \%$ & $11.18 \%$ & $11.44 \%$ & $11.84 \%$ & $11.86 \%$ & $12.31 \%$ & $12.24 \%$ & $11.91 \%$ & $12.08 \%$ \\
\hline & $(0.580)$ & $(0.592)$ & $(0.620)$ & $(0.634)$ & $(0.649)$ & $(0.653)$ & $(0.676)$ & $(0.668)$ & $(0.692)$ & $(0.683)$ & $(0.666)$ & $(0.673)$ \\
\hline \multirow[t]{2}{*}{ 20_20 } & $9.26 \%$ & $9.51 \%$ & $9.92 \%$ & $10.26 \%$ & $10.59 \%$ & $10.82 \%$ & $11.17 \%$ & $11.30 \%$ & $11.68 \%$ & $11.70 \%$ & $11.35 \%$ & $11.67 \%$ \\
\hline & $(0.611)$ & $(0.614)$ & $(0.635)$ & (0.649) & $(0.657)$ & (0.659) & $(0.681)$ & $(0.678)$ & $(0.700)$ & $(0.693)$ & $(0.673)$ & $(0.686)$ \\
\hline
\end{tabular}

<표 5>에서 $\mathrm{BLCF}$ 는 <표 4>와 동일하게 9 10개월 동안의 수익률 갭을 기준으로 투자를 진행했을 때, 최적의 결과를 얻을 수 있다. 결과적으로 KOSPI, MSCI World 지수를 이용하여 포트폴리오를 구성할 때, 환율의 영향에 관계없이 최근 9 10개월 데이터를 기반으로 경기 국면을 파악할 때 최적의 결과를 얻을 수 있다. 이하에서는 경기국면변수의 최적시차 $\mathrm{n}$ 을 9 로 가정한다.

\section{〈표 5〉 투자기간 및 모멘텀 기간에 따른 BLCF의 수익률 및 샤프지수}

1975.01.31 2018.05.31 기간 동안 환헤지의 가정 하에서 투자기간 및 모멘텀 기간에 따른 BLCF의 수익률 및 샤프지수를 도출한 데이터이다. 환헤지의 가정이므로 MSCI World 지수의 수익률은 지수변화율만을 고려하여 산출하였다. BLCF 모델의 투자전략은 두 가지로 구분된다. 첫 번째는 시간에 따라 신흥시장에서 글로벌 시장 지수로 투자비중을 이전하는 전략이다. 이 전략은 전환기간(P1)과 전환 후 투자기간(P2)에 의하여 투자비중의 이전속도가 변화한다는 특징이 있다. 전환기간이란 시간에 따라 투자비중을 신흥시장에서 글로벌시장으로 전환하는 기간을 의미하며, 초기에는 신흥시장 지수에 전액 투자하되, 전환기간 동안 글로벌시장 지수로 투자비중을 동일비중 이전한다. 모멘텀에 변화가 없는 한, 전환기간의 종료시점에는 글로벌시장 지수로 투자비중이 전액 투자된다. 전환 후 투자기간은 모멘텀에 변화가 없는 한, 글로벌시장 지수로 전액 투자한 상태로 투자를 유지하는 기간을 의미한다. <표 5>의 세로축은 전환기간 (P1)과 전환 후 투자기간(P2)을 나타낸다. BLCF 모델의 두 번째 전략은 수익률 모멘텀에 따라 투자비중을 이전하는 방식이다. 이 전략은 신훙시장이 글로벌 시장보다 $\mathrm{n}$ 개월 동안의 누적수익률이 $1 \% \mathrm{p}$ 증가할 때마다 신흥시장으로 비중을 $1 \% \mathrm{p}$ 이전하며, 반대로 글로벌시장의 $\mathrm{n}$ 개월 누적수익률이 $1 \% \mathrm{p}$ 증가할 때마다 글로벌시장으로 비중을 $1 \% \mathrm{p}$ 이전한다. 투자시작시점에 따라 투자결과가 다르게 도출될 수 있다는 점을 감안하여 총 투자기간이 20년, 25년, 30년, 35년, 40년일 때 각각 1975.01.31 1998.05.31, 1975.01.31 1993.05.31, 1975.01.31 1988.05.31, 1975.01.31 1983.05.31, 1975.01.31 1978.05.31를 투자시작시점 으로 하여 결과를 도출하고 이 결과들의 평균치를 기록하였다. 투자수익률의 경우 수익률을 연율화 하였다. <표 $5>$ 의 가로축은 모멘텀 산출 기간(n, 단위: 월)을 나타낸다. 괄호 밖의 데이터는 연 평균 투자수익률, 괄호 안의 데이터는 샤프지수를 나타낸다.

\begin{tabular}{rcccccccccccc}
\hline & 1 & 2 & 3 & 4 & 5 & 6 & 7 & 8 & $9 *$ & $10 *$ & 11 & 12 \\
\hline $10 \_10$ & $7.62 \%$ & $7.71 \%$ & $7.93 \%$ & $8.18 \%$ & $8.55 \%$ & $8.74 \%$ & $9.11 \%$ & $9.25 \%$ & $9.31 \%$ & $9.31 \%$ & $9.27 \%$ & $9.13 \%$ \\
& $(0.474)$ & $(0.471)$ & $(0.480)$ & $(0.491)$ & $(0.507)$ & $(0.507)$ & $(0.531)$ & $(0.530)$ & $(0.532)$ & $(0.531)$ & $(0.526)$ & $(0.517)$ \\
\hline
\end{tabular}


한국증권학회지 제48권 6호 (2019)

〈표 5〉 투자기간 및 모멘텀 기간에 따른 BLCF의 수익률 및 샤프지수(계속)

\begin{tabular}{lcccccccccccc}
\hline & 1 & 2 & 3 & 4 & 5 & 6 & 7 & 8 & $9 *$ & $10 *$ & 11 & 12 \\
\hline $15 \_10$ & $7.69 \%$ & $7.78 \%$ & $8.10 \%$ & $8.46 \%$ & $8.76 \%$ & $8.83 \%$ & $9.17 \%$ & $9.44 \%$ & $9.48 \%$ & $9.37 \%$ & $9.17 \%$ & $9.03 \%$ \\
& $(0.493)$ & $(0.489)$ & $(0.503)$ & $(0.520)$ & $(0.531)$ & $(0.523)$ & $(0.543)$ & $(0.546)$ & $(0.547)$ & $(0.540)$ & $(0.527)$ & $(0.515)$ \\
$10 \_15$ & $7.84 \%$ & $7.95 \%$ & $8.14 \%$ & $8.42 \%$ & $8.77 \%$ & $8.93 \%$ & $9.28 \%$ & $9.36 \%$ & $9.51 \%$ & $9.42 \%$ & $9.38 \%$ & $9.17 \%$ \\
& $(0.477)$ & $(0.475)$ & $(0.480)$ & $(0.490)$ & $(0.503)$ & $(0.503)$ & $(0.523)$ & $(0.517)$ & $(0.524)$ & $(0.517)$ & $(0.513)$ & $(0.501)$ \\
$10 \_20$ & $8.14 \%$ & $8.28 \%$ & $8.65 \%$ & $9.04 \%$ & $9.27 \%$ & $9.26 \%$ & $9.58 \%$ & $9.92 \%$ & $9.92 \%$ & $9.89 \%$ & $9.62 \%$ & $9.56 \%$ \\
& $(0.525)$ & $(0.525)$ & $(0.542)$ & $(0.561)$ & $(0.569)$ & $(0.556)$ & $(0.576)$ & $(0.582)$ & $(0.582)$ & $(0.578)$ & $(0.561)$ & $(0.553)$ \\
$15 \_15$ & $8.34 \%$ & $8.48 \%$ & $8.76 \%$ & $9.13 \%$ & $9.40 \%$ & $9.46 \%$ & $9.78 \%$ & $9.99 \%$ & $10.11 \%$ & $10.05 \%$ & $9.88 \%$ & $9.75 \%$ \\
& $(0.519)$ & $(0.519)$ & $(0.529)$ & $(0.545)$ & $(0.553)$ & $(0.547)$ & $(0.565)$ & $(0.565)$ & $(0.571)$ & $(0.565)$ & $(0.554)$ & $(0.544)$ \\
$20 \_10$ & $8.42 \%$ & $8.56 \%$ & $8.71 \%$ & $8.99 \%$ & $9.33 \%$ & $9.50 \%$ & $9.84 \%$ & $9.86 \%$ & $10.06 \%$ & $9.99 \%$ & $10.01 \%$ & $9.79 \%$ \\
& $(0.498)$ & $(0.498)$ & $(0.501)$ & $(0.510)$ & $(0.522)$ & $(0.525)$ & $(0.544)$ & $(0.536)$ & $(0.548)$ & $(0.540)$ & $(0.540)$ & $(0.529)$ \\
$15 \_20$ & $7.88 \%$ & $8.03 \%$ & $8.32 \%$ & $8.69 \%$ & $8.89 \%$ & $8.89 \%$ & $9.21 \%$ & $9.52 \%$ & $9.55 \%$ & $9.55 \%$ & $9.31 \%$ & $9.31 \%$ \\
& $(0.504)$ & $(0.506)$ & $(0.518)$ & $(0.535)$ & $(0.541)$ & $(0.531)$ & $(0.549)$ & $(0.556)$ & $(0.558)$ & $(0.554)$ & $(0.539)$ & $(0.535)$ \\
$20 \_15$ & $8.00 \%$ & $8.10 \%$ & $8.34 \%$ & $8.70 \%$ & $8.95 \%$ & $8.99 \%$ & $9.33 \%$ & $9.51 \%$ & $9.66 \%$ & $9.60 \%$ & $9.46 \%$ & $9.35 \%$ \\
& $(0.494)$ & $(0.493)$ & $(0.500)$ & $(0.515)$ & $(0.524)$ & $(0.519)$ & $(0.538)$ & $(0.537)$ & $(0.546)$ & $(0.539)$ & $(0.532)$ & $(0.524)$ \\
$20 \_20$ & $7.75 \%$ & $7.85 \%$ & $8.05 \%$ & $8.36 \%$ & $8.46 \%$ & $8.48 \%$ & $8.77 \%$ & $8.98 \%$ & $9.06 \%$ & $9.03 \%$ & $8.81 \%$ & $8.80 \%$ \\
& $(0.508)$ & $(0.506)$ & $(0.513)$ & $(0.527)$ & $(0.526)$ & $(0.520)$ & $(0.537)$ & $(0.538)$ & $(0.545)$ & $(0.538)$ & $(0.524)$ & $(0.521)$ \\
\hline
\end{tabular}

\subsection{Vintage 분석을 통한 투자기간 결정}

<그림 1>, <표 6>은 세 가지 시사점을 가진다. 먼저 총 투자기간이 짧을수록 투자 시작시점에 따른 수익률 변화가 크게 발생한다. $(\mathrm{P} 1, \mathrm{P} 2)=(10,10)$ 의 투자기간을 가지는 $\mathrm{BLCF}$ 의 경우 투자 시작시점에 따라 5.88 20.43\%의 연평균수익률을 가지는 반면, $(\mathrm{P} 1, \mathrm{P} 2)=(20,20)$ 의 투자기간을 가지는 $\mathrm{BLCF}$ 는 $11.04 \sim 12.08 \%$ 의 연평균수익률을 가진다.

다음으로 총 투자기간이 동일할 때 전환기간이 길수록 평균수익률이 약간 개선되나, 투자시점에 따른 수익률 변화가 크게 발생하며 투자기간동안 변동성이 커지면서 샤프지수가 악화되는 경향이 있다. 이러한 사실은 다음의 두 가지 근거에 기인한다. 첫째, 전환 후 투자기간의 비중이 길어질수록 $\mathrm{BLCF}$ 는 글로벌시장 비중을 늘려 안정성을 강하게 확보할 수 있고 이에 대한 결과는 샤프지수의 개선으로 나타난다. 둘째, 전환기간의 비중이 늘어날수록 신훙시장의 비중을 늘려 성장성을 확보할 수 있으며, 이는 수익률의 개선으로 나타난다.

마지막으로 수익률과 샤프지수를 고려할 때, $\mathrm{BLCF}$ 는 투자기간이 30년일 때 가장 높은 성과를 달성한다. 최대성과만을 고려할 경우, 투자기간이 가장 짧은 $(\mathrm{P} 1, \mathrm{P} 2)=(10,10)$ 의 투자기간을 가지는 $\mathrm{BLCF}$ 가 가장 바람직하다 그러나 본 연구는 연금펀드의 구상을 목적으로 하는 만큼, 성과를 극대화하면서도 가입시점에 따른 불안요인을 최소화하는 것이 바람직하다. 따라서 최대성과보다는 평균적인 성과가 극대화되는 투자기간을 선택하는 것이 바람직하다.

<표 6>에서 수익률과 샤프지수가 모두 총 투자기간이 30년일 때 극대화된다. 구체적으로 수익률은 $(\mathrm{P} 1, \mathrm{P} 2)=(20,10)$, 샤프지수는 $(\mathrm{P} 1, \mathrm{P} 2)=(10,20)$ 일 경우 극대화된다는 것을 알 수 있다. 샤프지수는 위험 대비 수익률의 성과를 측정한다는 점에서 단순하게 수익률만으로 
An Investment Strategy Based on Life and Business Cycles

투자기간을 설정하는 것보다 바람직할 수 있다. 따라서 이하의 연구에서는 투자기간을 (P1, $\mathrm{P} 2)=(10,20)$ 으로 설정하여 $\mathrm{BLCF}$ 의 성과를 분석한다.

\section{<그림 1> Vintage 수익률 및 샤프지수}

BLCF Ex 모델의 거래방식을 기반으로 1975.01.31 2018.05.31 기간 동안 투자하였을 때의 투자기간별 Vintage 수익률 및 샤프지수를 나타낸다. Vintage란 투자시작시점에 따라 수익률이 달라질 수 있다는 점에 착안하여 펀드의 조성 시점을 일컫는 용어이다. 본문에서는 Vintage 수익률을 투자시작시점을 변화시켰을 때의 BLCF Ex 모델의 연평균 수익률 집합으로 정의한다. BLCF Ex란 환노출의 가정 하에서 $\mathrm{BLCF}$ 모델의 투자전략을 진행한 모델을 의미한다. 환노출의 가정이므로 MSCI World 지수의 수익률은 지수변화율에 환율 변화율을 더하여 산출하였다. BLCF 모델의 투자전략은 두 가지로 구분된다. 첫 번째는 시간에 따라 신흥시장에서 글로벌 시장 지수로 투자비중을 이전하는 전략이다. 이 전략은 전환기간(P1)과 전환 후 투자기간(P2)에 의하여 투자비중의 이전속도가 변화한다는 특징이 있다. 전환기간이란 시간에 따라 투자비중을 신흥시장에서 글로벌시장으로 전환하는 기간을 의미하며, 초기에는 신흥시장 지수에 전액 투자하되, 전환기간 동안 글로벌시장 지수로 투자비중을 동일비중 이전한다. 모멘텀에 변화가 없는 한, 전환기간의 종료시점에는 글로벌시장 지수로 투자비중이 전액 투자된다. 전환 후 투자기간은 모멘텀에 변화가 없는 한, 글로벌시장 지수로 전액 투자한 상태로 투자를 유지하는 기간을 의미한다. BLCF 모델의 두 번째 전략은 수익률 모멘텀에 따라 투자비중을 이전하는 방식이다. 이 전략은 신흥시장이 글로벌 시장보다 $\mathrm{n}$ 개월 동안의 누적수익률이 $1 \% \mathrm{p}$ 증가할 때마다 신흥시장으로 비중을 $1 \% \mathrm{p}$ 이전하며, 반대로 글로벌시장의 $\mathrm{n}$ 개월 누적수익률이 $1 \% \mathrm{p}$ 증가할 때마다 글로벌시장으로 비중을 $1 \% \mathrm{p}$ 이전한다. 아래의 두 그래프 중 상단의 그래프는 Vintage 연평균 수익률, 하단의 그래프는 샤프지수를 나타낸다.
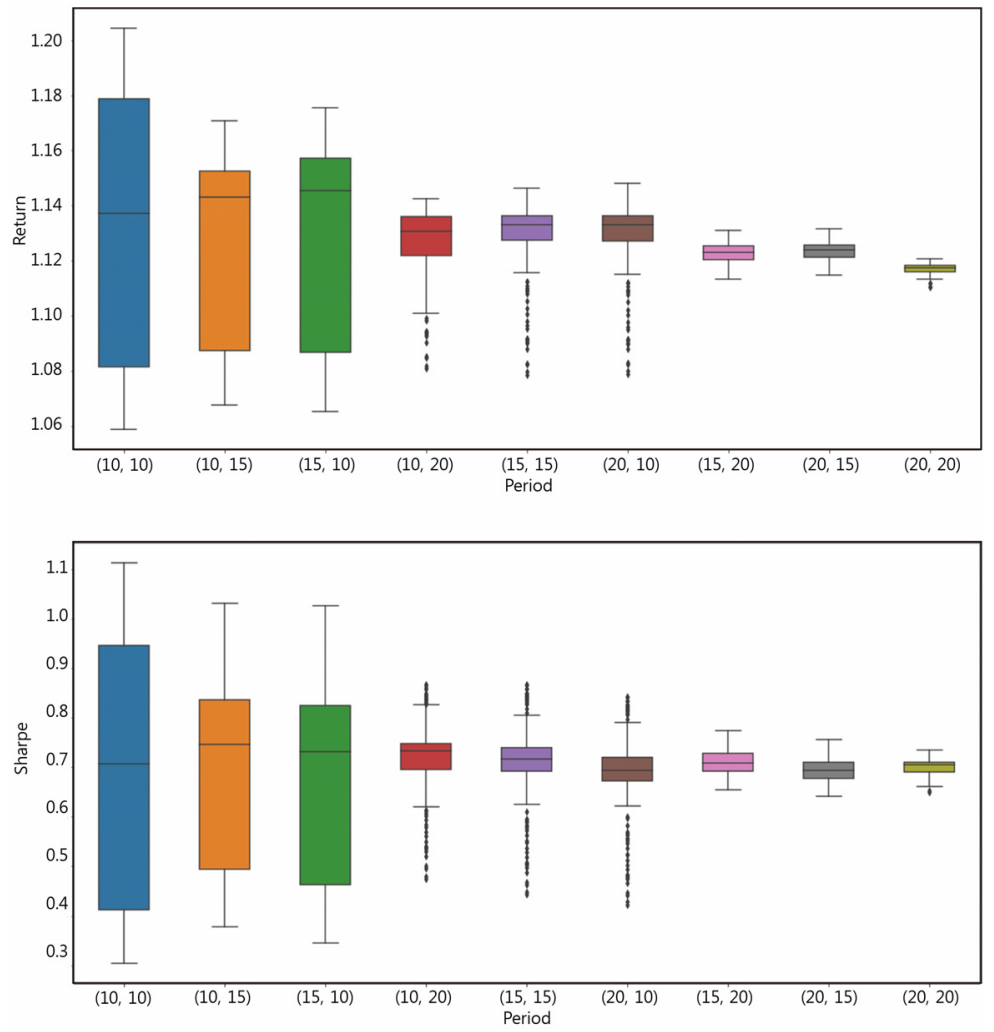
〈표 6〉Vintage 수익률 및 샤프지수의 요약 통계량

BLCF Ex 모델의 거래방식을 기반으로 1975.01.31 2018.05.31 기간 동안 투자하였을 때의 Vintage 수익률 및 샤프지수의 요약 통계량을 나타낸다. Vintage란 투자시작시점에 따라 수익률이 달라질 수 있다는 점에 착안하여 펀드의 조성 시점을 일컫는 용어이다. 본문에서는 Vintage 수익률을 투자시작 시점을 변화시켰을 때의 $\mathrm{BLCF} \mathrm{Ex}$ 모델의 연평균 수익률 집합으로 정의한다. $\mathrm{BLCF} \mathrm{Ex}$ 란 환노출의 가정 하에서 $\mathrm{BLCF}$ 모델의 투자전략을 진행한 모델을 의미한다. 환노출의 가정이므로 MSCI World 지수의 수익률은 지수변화율에 환율 변화율을 더하여 산출하였다. BLCF 모델의 투자전략은 두 가지로 구분된다. 첫 번째는 시간에 따라 신흥시장에서 글로벌 시장 지수로 투자비중을 이전하는 전략이다. 이 전략은 전환기간(P1)과 전환 후 투자기간(P2)에 의하여 투자비중의 이전속도가 변화한다는 특징이 있다. 전환기간이란 시간에 따라 투자비중을 신흥시장에서 글로벌시장으로 전환하는 기간을 의미하며, 초기에는 신흥시장 지수에 전액 투자하되, 전환기간 동안 글로벌시장 지수로 투자비중을 동일비중 이전한다. 모멘텀에 변화가 없는 한, 전환기간의 종료시점에는 글로벌시장 지수로 투자비중이 전액 투자된다. 전환 후 투자기간은 모멘텀에 변화가 없는 한, 글로벌시장 지수로 전액 투자한 상태로 투자를 유지하는 기간을 의미한다. $\mathrm{BLCF}$ 모델의 두 번째 전략은 수익률 모멘텀에 따라 투자비중을 이전하는 방식이다. 이 전략은 신흥시장이 글로벌 시장보다 $\mathrm{n}$ 개월 동안의 누적수익률이 $1 \% \mathrm{p}$ 증가할 때마다 신흥시장으로 비중을 $1 \% \mathrm{p}$ 이전하며, 반대로 글로벌시장의 $\mathrm{n}$ 개월 누적수익률이 $1 \% \mathrm{p}$ 증가할 때마다 글로벌시장으로 비중을 $1 \% \mathrm{p}$ 이전한다. 투자시작시점에 따라 투자결과가 다르게 도출될 수 있다는 점을 감안하여 총 투자기간이 20년, 25년, 30년, 35년, 40년일 때 각각 1975.01.31 1998.05.31, 1975.01.31 1993.05.31, 1975.01.31 1988.05.31, 1975.01.31 1983.05.31, 1975.01.31 1978.05.31을 투자시작시점으로 하여 결과를 도출하고 이 결과들의 평균치를 기록하였다. 투자수익률의 경우 수익률을 연율화 하였다. <표 6>의 가로축은 Vintage 수익률의 요약 통계량을, 세로축은 전환기간 (P1)과 전환 후 투자기간(P2)을 나타낸다.

\begin{tabular}{|c|c|c|c|c|c|c|c|c|}
\hline (P1 & P2) & mean & std & $\min (=0)$ & 0.25 & 0.5 & 0.75 & $\max (=1)$ \\
\hline \multirow[t]{2}{*}{$(10,10)$} & return & $12.79 \%$ & 0.0469 & $5.88 \%$ & $8.14 \%$ & $13.73 \%$ & $17.88 \%$ & $20.43 \%$ \\
\hline & sharpe & 0.692 & 0.273 & 0.304 & 0.412 & 0.707 & 0.947 & 1.113 \\
\hline \multirow[t]{2}{*}{$(10,15)$} & return & $12.56 \%$ & 0.0329 & $6.77 \%$ & $8.73 \%$ & $14.32 \%$ & $15.26 \%$ & $17.08 \%$ \\
\hline & sharpe & 0.689 & 0.182 & 0.378 & 0.494 & 0.746 & 0.837 & 1.031 \\
\hline \multirow[t]{2}{*}{$(15,10)$} & return & $12.71 \%$ & 0.0354 & $6.53 \%$ & $8.68 \%$ & $14.53 \%$ & $15.73 \%$ & $17.55 \%$ \\
\hline & sharpe & 0.669 & 0.193 & 0.345 & 0.463 & 0.732 & 0.826 & 1.027 \\
\hline \multirow[t]{2}{*}{$(10,20)$} & return & $12.66 \%$ & 0.0136 & $8.09 \%$ & $12.19 \%$ & $13.07 \%$ & $13.61 \%$ & $14.26 \%$ \\
\hline & sharpe & 0.719 & 0.084 & 0.474 & 0.696 & 0.733 & 0.749 & 0.868 \\
\hline \multirow[t]{2}{*}{$(15,15)$} & return & $12.87 \%$ & 0.0151 & $7.86 \%$ & $12.74 \%$ & $13.32 \%$ & $13.63 \%$ & $14.62 \%$ \\
\hline & sharpe & 0.707 & 0.094 & 0.443 & 0.693 & 0.717 & 0.740 & 0.867 \\
\hline \multirow[t]{2}{*}{$(20,10)$} & return & $12.90 \%$ & 0.0155 & $7.88 \%$ & $12.73 \%$ & $13.30 \%$ & $13.62 \%$ & $14.79 \%$ \\
\hline & sharpe & 0.685 & 0.094 & 0.423 & 0.673 & 0.695 & 0.720 & 0.843 \\
\hline \multirow[t]{2}{*}{$(15,20)$} & return & $12.24 \%$ & 0.0043 & $11.33 \%$ & $12.05 \%$ & $12.30 \%$ & $12.54 \%$ & $13.11 \%$ \\
\hline & sharpe & 0.709 & 0.029 & 0.655 & 0.692 & 0.710 & 0.728 & 0.774 \\
\hline \multirow[t]{2}{*}{$(20,15)$} & return & $12.31 \%$ & 0.0042 & $11.47 \%$ & $12.12 \%$ & $12.39 \%$ & $12.56 \%$ & $13.16 \%$ \\
\hline & sharpe & 0.692 & 0.028 & 0.641 & 0.677 & 0.694 & 0.710 & 0.756 \\
\hline \multirow[t]{2}{*}{$(20,20)$} & return & $11.68 \%$ & 0.0028 & $11.04 \%$ & $11.60 \%$ & $11.75 \%$ & $11.84 \%$ & $12.08 \%$ \\
\hline & sharpe & 0.700 & 0.022 & 0.651 & 0.690 & 0.705 & 0.710 & 0.735 \\
\hline
\end{tabular}

\section{5 투자수익률 및 샤프지수를 이용한 지수 간 비교, 분석}

$\mathrm{BLCF}$ 는 환율에 관계없이 $\mathrm{KOSPI}, \mathrm{MSCI}$ World에 대한 단일지수 투자보다 수익률 및 샤프지수에서 명백한 개선을 보인다. 구체적으로 MSCI World 지수를 비교대상으로 할 때, 
An Investment Strategy Based on Life and Business Cycles

BLCF는 World 지수에 비해 약 2 3\%p만큼의 연간 수익률 개선을 보인다. 또한 샤프지수 역시 BLCF는 World 지수에 비해 모든 기간에서 개선되었음을 볼 수 있다.

〈표 7〉 각각의 지수에 대한 투자수익률 및 샤프지수의 요약통계량 각각의 지수에 대한 연평균 투자수익률 및 샤프지수의 요약통계량이다. 환노출의 상황에서 투자결과를 도출한 경우 $\mathrm{Ex}$ 를 붙여 나타내었다. 요약통계량은 투자시작시점을 1975.01.31부터 1988.05.31까지 매월 말일로 두고 30 년간 투자하였을 때의 161 개의 투자결과를 사용하였다. BLCF, BLCF Ex, BLCF Li, $\mathrm{BLCF} \mathrm{Li} \mathrm{Ex}$ 의 경우 30 년간의 투자기간 중 10 년을 전환기간, 20 년을 전환 후 투자기간으로 두고 모델을 구상하였다.

\begin{tabular}{|c|c|c|c|c|c|c|c|c|}
\hline & & mean & std & $\min (=0)$ & 0.25 & 0.5 & 0.75 & $\max (=1)$ \\
\hline \multirow{2}{*}{ KOSPI } & return & $8.74 \%$ & 0.014 & $4.48 \%$ & $8.53 \%$ & $9.25 \%$ & $9.58 \%$ & $10.43 \%$ \\
\hline & sharpe & 0.306 & 0.045 & 0.165 & 0.294 & 0.324 & 0.334 & 0.360 \\
\hline \multirow{2}{*}{ World } & return & $7.37 \%$ & 0.012 & $4.70 \%$ & $6.86 \%$ & $7.45 \%$ & $7.98 \%$ & $9.66 \%$ \\
\hline & sharpe & 0.498 & 0.098 & 0.315 & 0.451 & 0.486 & 0.522 & 0.697 \\
\hline \multirow{2}{*}{ World_Ex } & return & $9.23 \%$ & 0.018 & $5.85 \%$ & $8.37 \%$ & $9.14 \%$ & $10.82 \%$ & $11.99 \%$ \\
\hline & sharpe & 0.589 & 0.100 & 0.391 & 0.547 & 0.584 & 0.657 & 0.753 \\
\hline \multirow{2}{*}{ BLCF } & return & $9.92 \%$ & 0.013 & $6.22 \%$ & $9.24 \%$ & $10.23 \%$ & $10.85 \%$ & $11.55 \%$ \\
\hline & sharpe & 0.582 & 0.086 & 0.365 & 0.537 & 0.588 & 0.623 & 0.729 \\
\hline \multirow{2}{*}{ BLCF_Ex } & return & $12.66 \%$ & 0.014 & $8.09 \%$ & $12.19 \%$ & $13.07 \%$ & $13.61 \%$ & $14.26 \%$ \\
\hline & sharpe & 0.719 & 0.084 & 0.474 & 0.696 & 0.733 & 0.749 & 0.868 \\
\hline \multirow{2}{*}{ BLCF Li } & return & $8.13 \%$ & 0.012 & $4.87 \%$ & $7.57 \%$ & $8.41 \%$ & $8.92 \%$ & $9.94 \%$ \\
\hline & sharpe & 0.524 & 0.080 & 0.307 & 0.480 & 0.534 & 0.589 & 0.638 \\
\hline \multirow{2}{*}{ BLCF Li Ex } & return & $9.56 \%$ & 0.011 & $5.98 \%$ & $8.96 \%$ & $9.72 \%$ & $10.36 \%$ & $11.40 \%$ \\
\hline & sharpe & 0.598 & 0.069 & 0.379 & 0.558 & 0.611 & 0.655 & 0.702 \\
\hline
\end{tabular}

〈그림 2〉 투자기간이 $(\mathrm{P} 1, \mathrm{P} 2)=(10,20)$ 인 $\mathrm{BLCF}$ 의 투자 시작시점에 따른 수익률 변화 $1975.01 .31 \sim 2018.05 .31$ 기간 동안 투자시작시점을 달리하여 $(\mathrm{P} 1, \mathrm{P} 2)=(10,20)$ 의 투자기간을 가지는 $\mathrm{BLCF}$ 와 KOSPI 지수, MSCI World 지수에 각각 30년 동안 투자했을 때, 투자결과를 연평균수익률 (시간가중)로 산출하여 나타낸 데이터이다. X축은 투자시작년도를 나타내며, BLCF 모형 및 MSCI World 지수에 대한 투자는 환노출의 가정 하에서 진행하였다.

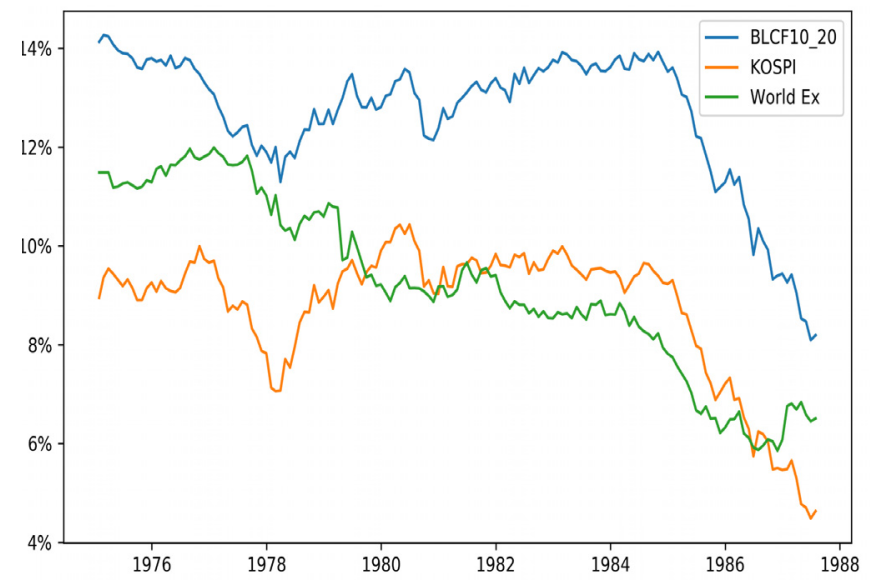


다음으로 BLCF 모형의 환율효과는 약 2 3\%로 BLCF Li에 비해 뚜렷한 개선효과가 나타난다. 이는 침체기에 KOSPI 지수에서 MSCI World 지수로의 비중 이전에 기인하는 것으로 보인다. 구체적으로 KOSPI 지수의 악화가 환율을 상승시키는 압력으로 작용하면서, World 지수의 투자수익률을 증가시키고 이러한 상황이 $\mathrm{BLCF}$ 의 환율효과를 극대화하는 것으로 분석된다.

종합하면, $\mathrm{BLCF}$ 는 단일지수 투자에 비해 높은 수익률과 샤프지수를 이끌어내며, BLCF의 성과를 극대화하기 위해서는 환율의 영향을 제거하지 않는 것이 바람직하다.

투자 결과 $\mathrm{BLCF}$ 투자모형은 단일지수투자의 경우보다 모든 기간에서 더 높은 수익률을 확보할 수 있다. 이는 BLCF 투자모형을 사용할 경우, 시장수익률을 초과하는 알파수익률을 얻을 수 있음을 의미한다.

\section{6 특정 시점(최대성과, 최소성과 시기)의 투자수익금 및 투자비중 분석}

투자수익금의 변화를 보면, <그림 3> 패널 A에서 BLCF는 신흥시장과 글로벌시장 중 수익률이 개선되는 시장을 추종하며, 그 결과 투자수익금이 두 시장에 비해 높게 나타난다. 이는 시장상황이 정체되어 있는 <그림 $3>$ 패널 $\mathrm{B}$ 의 경우에도 동일하게 성립한다.

\section{〈그림 3〉 특정시점의 투자결과 분석}

$(\mathrm{P} 1, \mathrm{P} 2)=(10,20)$ 의 투자기간을 가지는 BLCF가 투자수익률이 가장 높을 때와 가장 낮을 때의 투자수익금의 궤적과, 이때의 투자비중 변화를 나타낸 그래프이다. 패널 A의 투자기간은 1975.12 2005.12이며, 패널 $\mathrm{B}$ 의 투자기간은 1988.05 2018.05이다. 투자수익금을 비교하기 위하여 동일기간 동안 단일지수 투자의 결과를 그래프에 같이 첨부하였다. 또한 경기국면 변수가 투자비중을 얼마나 변화시키는지 확인하기 위해 단순한 생애주기 가설만을 고려했을 경우의 그래프를 투자비중 그래프에 같이 첨부하였다. BLCF 및 MSCI World 지수의 결과물은 환노출의 가정 하에서 진행하였다.

패널 A: BLCF 10_20의 최대 성과 시 지수와 비중 변화
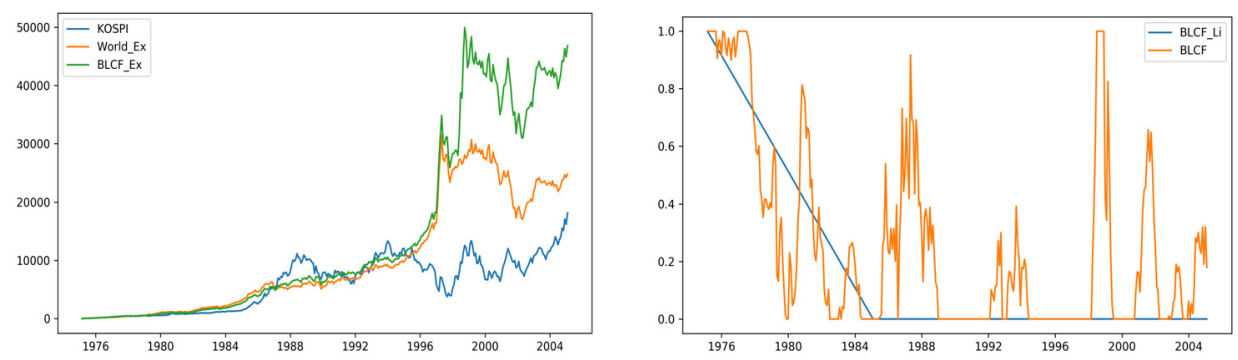

패널 B: BLCF 10_20의 최소 성과 시 지수와 비중 변화
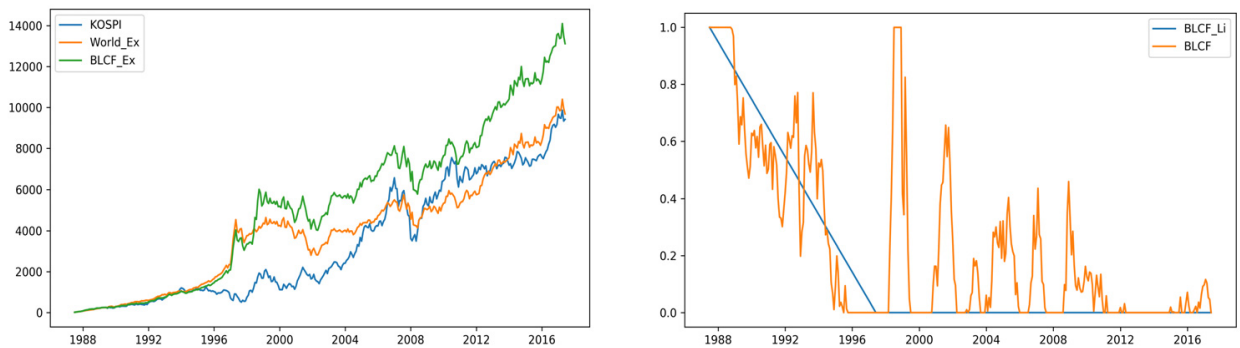
다음으로 투자비중의 변화를 보면, 경기국면 변수에 따라 BLCF가 수익률이 높은 시장을 추종하면서 글로벌 시장과 신흥시장 간의 투자비중을 지속적으로 변화시키고 있음을 보여준다. 또한 일시적으로 KOSPI지수와 MSCI World 지수가 음의 상관성을 보이는 구간에서 지수가 KOSPI에 100\% 투자하는 경우가 발생한다. 그러나 생애주기 투자방식에 따라 전환 후 투자기간 동안(MSCI World 지수에 $100 \%$ 투자)에는 음의 상관성을 보이더라도 KOSPI로의 비중이전은 전환기간에 비해 작아지며, 지수는 MSCI World의 움직임과 유사하게 변화한다. 요약하자면, $\mathrm{BLCF}$ 는 경기국면을 고려함에 따라 시장수익률을 초과하는 수익률을 얻을 수 있으며, 생애주기에 따라 시간이 지날수록 안전자산의 성격을 강화한다.

\section{BLCF-H Model}

$\mathrm{BLCF}$ 모형은 경기변동에 대한 두 가지 가정 하에서 단일지수투자보다 높은 수익률을 얻을 수 있다. 그러나 BLCF 모형은 글로벌 리스크에 취약하다는 단점이 있다. 금융의 세계화로 인해 주가지수는 글로벌 경기에 순행적인 성격이 강하며, 주가지수를 투자 대상으로 하는 BLCF 모형은 2008년 금융위기와 같은 글로벌 경기침체에 대해 여전히 취약하다. 따라서 본 연구에서는 경기침체 판별변수(RS: Recession Sign)를 설정하여 글로벌 경기침체에 대한 취약점을 보완하고자 하였다.

\subsection{BLCF-H 모형 생성방식}

$(\mathrm{P} 1, \mathrm{P} 2)=(10,20)$ 으로 고정하였으며 경기국면변수의 최적시차는 9 개월로 설정하였다. 안전 자산에 달러화가 포함됨에 따라 왜곡을 피하기 위하여 본 분석에서는 환율의 영향력을 제외하고 결과를 도출하였다.

금융시장과 무관하여 금융시장 리스크로부터 안전하거나 혹은 시장이 불안정할 때, 오히려 수익률이 개선되는 경기역행적인 자산인 금, 미 국채, 미국 달러화를 안전자산으로 선정하였다. 미 국채의 경우, 미국 달러화와의 비교를 위하여 환헤지의 상황을 가정하였다. BLCF-H 모형 에서의 비중 변화는 다음과 같다.

경기침체 판별변수

$$
R S_{t}=\prod_{i=1}^{6} \operatorname{Ret}_{E M, t-i}+\prod_{i=1}^{6} \operatorname{Ret}_{G M, t-i}
$$

경기국면변수

$$
\operatorname{Gap}_{t}=\prod_{i=1}^{9} \operatorname{Ret}_{E M, t-i}-\prod_{i=1}^{9} \operatorname{Ret}_{G M, t-i}
$$

시간(t)의 변화에 따른 투자비중 $(\mathrm{W})$ 변화는 다음과 같다.

$$
t=0,\left(W_{E M}, W_{G M}\right)=(1,0)
$$




$$
\begin{aligned}
& 0<t \leq P_{1}, \quad\left(W_{E M}, W_{G M}\right)=\left(1-\frac{t}{P_{1}}+G_{a p}, 0+\frac{t}{P_{1}}-\operatorname{Gap}_{t}\right) \\
& P_{1}<t \leq P_{2}, \quad\left(W_{E M}, W_{G M}\right)=\left(G_{a p}, 1-G a p_{t}\right) \\
& \text { 단, } W_{E M}\left(\text { or } W_{G M}\right)<0 \text { 이면, } W_{E M}\left(\text { or } W_{G M}\right)=0, \\
& W_{E M}\left(\text { or } W_{G M}\right)>1 \text { 이면, } W_{E M}\left(\text { or } W_{G M}\right)=1, \\
& R S<-20 \% \text { 경우, }\left(W_{E M}, W_{G M}, W_{\text {Safe Asset }}\right)=(0,0,1)
\end{aligned}
$$

이 때, 호황은 경기가 지속적이고 완만하게 개선되는 반면, 불황은 급격하게 발생할 수 있다는 점에 의거하여 경기침체판별변수(RS)는 경기국면변수(Gap)보다 더 짧은 기간을 반영하였다.2)

\section{2 투자 수익률 및 샤프지수의 평균치 분석}

<표 8>에서 금을 이용하여 시장리스크를 회피한 경우 $\mathrm{BLCF}$ 모형보다 낮은 평균 수익률을 보였으나, 미 국채나 미 달러를 이용하여 시장리스크를 회피한 경우에는 일반 BLCF 모형보다 높은 수익률을 얻을 수 있었다. KOSPI와 MSCI World 단일지수에 대한 투자보다는 세 경우 모두 높은 성과를 보였다. 다음으로 샤프지수를 보면 $\mathrm{BLCF}-\mathrm{H}$ 모형이 $\mathrm{BLCF}$ 모형이나 단일 지수에 대한 투자보다 항상 높은 성과를 보이는 것을 알 수 있다. 이를 통해 경기역행적인 안전자산을 섞는 것이 금융리스크를 회피하는데 있어 효과적임을 알 수 있다.

〈표 8〉 각각의 지수에 대한 투자수익률 및 샤프지수의 요약통계량

각각의 지수에 대한 연평균 투자수익률 및 샤프지수의 요약통계량이다. 미 달러의 헤지효과를 다른 자산들과

\begin{tabular}{|c|c|c|c|c|c|c|c|c|}
\hline & & mean & std & $\min (=0)$ & 0.25 & 0.5 & 0.75 & $\max (=1)$ \\
\hline BLCF-H & Return & $9.68 \%$ & 0.0141 & $6.70 \%$ & $8.78 \%$ & $9.40 \%$ & $10.69 \%$ & $12.08 \%$ \\
\hline (Gold) & Sharpe & 0.613 & 0.069 & 0.447 & 0.574 & 0.619 & 0.661 & 0.726 \\
\hline $\mathrm{BLCF}-\mathrm{H}$ & Return & $11.13 \%$ & 0.0139 & $7.80 \%$ & $10.30 \%$ & $11.12 \%$ & $12.25 \%$ & $13.22 \%$ \\
\hline (Bond) & Sharpe & 0.775 & 0.074 & 0.572 & 0.714 & 0.805 & 0.832 & 0.870 \\
\hline $\mathrm{BLCF}-\mathrm{H}$ & Return & $13.95 \%$ & 0.0161 & $10.76 \%$ & $12.72 \%$ & $14.14 \%$ & $15.32 \%$ & $16.35 \%$ \\
\hline$(\mathrm{Ex})$ & Sharpe & 0.849 & 0.066 & 0.673 & 0.797 & 0.875 & 0.896 & 0.936 \\
\hline \multirow[t]{2}{*}{ BLCF } & Return & $9.92 \%$ & 0.0128 & $6.22 \%$ & $9.24 \%$ & $10.23 \%$ & $10.85 \%$ & $11.55 \%$ \\
\hline & Sharpe & 0.582 & 0.086 & 0.365 & 0.537 & 0.588 & 0.623 & 0.729 \\
\hline \multirow[t]{2}{*}{ KOSPI } & Return & $8.74 \%$ & 0.0136 & $4.48 \%$ & $8.53 \%$ & $9.25 \%$ & $9.58 \%$ & $10.43 \%$ \\
\hline & Sharpe & 0.306 & 0.045 & 0.165 & 0.294 & 0.324 & 0.334 & 0.360 \\
\hline \multirow[t]{2}{*}{ MSCI World } & Return & $7.37 \%$ & 0.0123 & $4.70 \%$ & $6.86 \%$ & $7.45 \%$ & $7.98 \%$ & $9.66 \%$ \\
\hline & Sharpe & 0.498 & 0.098 & 0.315 & 0.451 & 0.486 & 0.522 & 0.697 \\
\hline
\end{tabular}
비교하기 위하여 미 달러에 투자하는 전략을 제외한 모든 투자에 있어서 환율 변동을 전혀 고려하지 않았다. 요약통계량은 투자시작시점을 1975.01.31부터 1988.05.31까지 매월 말일로 두고 30년간 투자하였을 때의 161 개의 투자결과를 사용하였다. $\mathrm{BLCF}-\mathrm{H}(\mathrm{Gold}), \mathrm{BLCF}-\mathrm{H}(\mathrm{Bond}), \mathrm{BLCF}-\mathrm{H}(\mathrm{Ex}), \mathrm{BLCF}$ 의 경우 30 년간의 투자기간 중 10 년을 전환기간, 20 년을 전환 후 투자기간으로 두고 모델을 구상하였다.

2) $\mathrm{RS}$ 의 시차 1 은 6 개월, $\mathrm{Gap}$ 의 시차 $\mathrm{n}$ 은 9 개월 반영. 
An Investment Strategy Based on Life and Business Cycles

\section{3 시간에 따른 투자수익률 분석}

일반 BLCF 모형과 금을 이용하여 금융리스크를 회피한 BLCF-H 모형의 경우 투자시작 시점에 따라 상대적인 우위에 있는 시점과 열위에 있는 시기가 존재한다. 그러나 이 외에 미 국채나 달러화를 이용하여 금융리스크를 회피하고자 한 경우에는 일반 BLCF 모형보다 월등히 좋은 성과를 내었다. 이를 통하여 BLCF-H 모형이 시장리스크를 효과적으로 회피했음을 알 수 있다.

\section{〈그림 4〉 투자시작시기에 따른 수익률 변화 (BLCF-H)}

1975.01.31 2018.05.31 기간 동안 투자시작시점을 다르게 하여 $(\mathrm{P} 1, \mathrm{P} 2)=(10,20)$ 의 투자기간을 가지는 $\mathrm{BLCF}, \mathrm{BLCF}-\mathrm{H}$ 와 KOSPI 지수, MSCI World 지수에 각각 30년 동안 투자했을 때의 투자결과를 연평균수익률(시간가중)로 산출하여 나타낸 데이터이다. X축은 투자시작년도를 나타내며 달러화를 이용한 환율 헤지의 성과를 나타내기 위해 달러화에 대한 투자 이외에는 환헤지를 가정하였다.

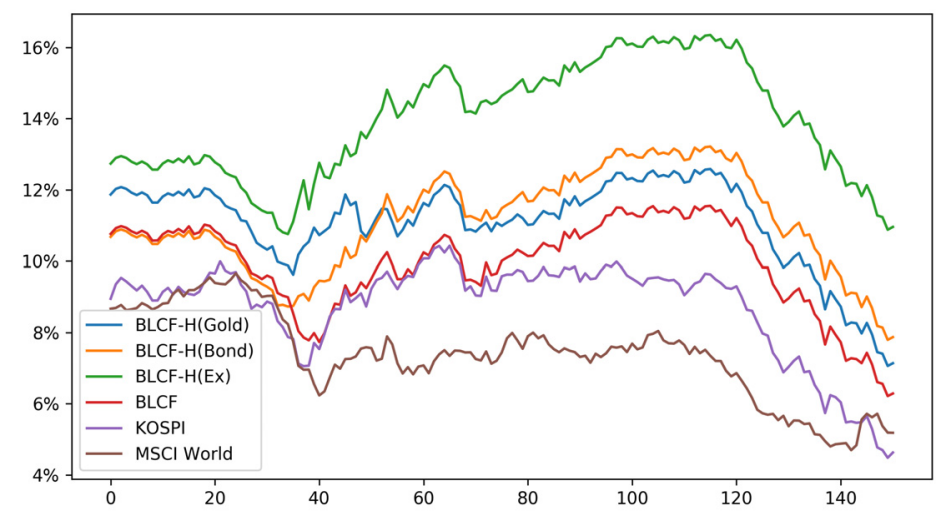

\section{4 특정 시점(최대성과, 최소성과 시기)의 투자수익금 및 투자비중 분석}

투자수익금의 변화를 보면, 패널 $\mathrm{A}$ 에서 $\mathrm{BLCF}-\mathrm{H}$ 는 BLCF 모형과 같이 신흥시장과 글로벌 시장 중 수익률이 개선되는 시장을 추종한다. 또한 두 시장 모두 위험을 겪을 경우 $\mathrm{BLCF}-\mathrm{H}$ 는 경기역행성 자산으로의 비중이전을 통하여 안정성을 확보하고 있다. 그 결과 $\mathrm{BLCF}-\mathrm{H}$ 의 최종 투자수익금은 BLCF 모형 및 시장지수들에 비하여 높다. 이를 통해 BLCF-H 모형의 위험회피 전략이 유효함을 알 수 있다. 이는 시장상황이 정체되어 있는 패널 $\mathrm{B}$ 의 경우에도 동일하게 성립한다. 회피자산별 결과는 두 시기 모두 달러화를 이용한 결과가 가장 좋은 성과를 보였으며 채권, 금이 그 뒤를 이었다.

투자비중의 변화는 수익금 개선의 원인에 대한 구체적인 설명을 제시한다. 먼저 BLCF-H는 $\mathrm{BLCF}$ 와 동일하게 생애주기에 따라 시간이 지날수록 글로벌 시장지수로 비중을 이전하며, 경기국면 변수에 따라 수익률이 높은 시장을 추종한다. 그러나 $\mathrm{BLCF}-\mathrm{H}$ 는 투자기간 중 어떤 시기이든 위기상황 발생 시 위험회피자산으로 비중을 지속적으로 전환하는 것을 알 수 있다. 이러한 안전자산으로의 비중전환이 추가적인 수익금 개선의 원인이 되는 것으로 분석된다. 
〈그림 5〉 특정시점의 투자결과 분석

$(\mathrm{P} 1, \mathrm{P} 2)=(10,20)$ 의 투자기간을 가지는 $\mathrm{BLCF}-\mathrm{H}$ 및 $\mathrm{BLCF}$ 가 투자수익률이 가장 높을 때와 가장 낮을 때의 투자수익금의 궤적과, 이때의 투자비중 변화를 나타낸 그래프이다. 패널 A의 투자기간은 1985.07 2015.07이며, 패널 B의 투자기간은 1988.05 2018.05이다. 투자수익금을 비교하기 위하여 동일기간 동안 단일지수 투자의 결과를 그래프에 같이 첨부하였다. 또한 경기국면 변수 및 경기침체판별변수가 투자비중을 얼마나 변화시키는지 확인하기 위해 단순한 생애주기 가설만을 고려했을 경우의 그래프를 투자비중 그래프에 같이 첨부하였다. 모든 투자 결과는 환헤지의 가정 하에서 도출되었다.

패널 $\mathrm{A}: \mathrm{BLCF}$ 및 $\mathrm{BLCF}-\mathrm{H}$ 의 최대 성과 시 지수와 비중 변화
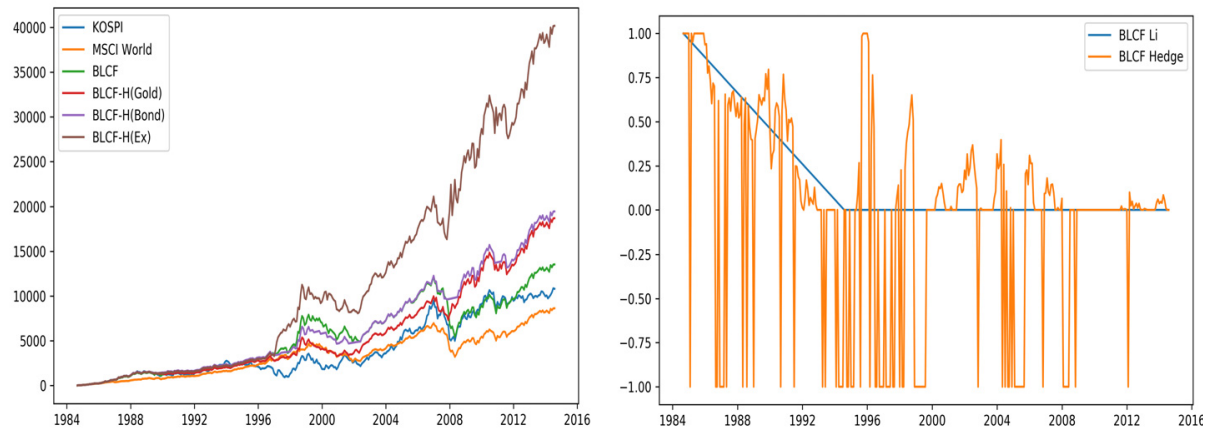

패널 $\mathrm{B}: \mathrm{BLCF}$ 및 $\mathrm{BLCF}-\mathrm{H}$ 의 최소 성과 시 지수와 비중 변화
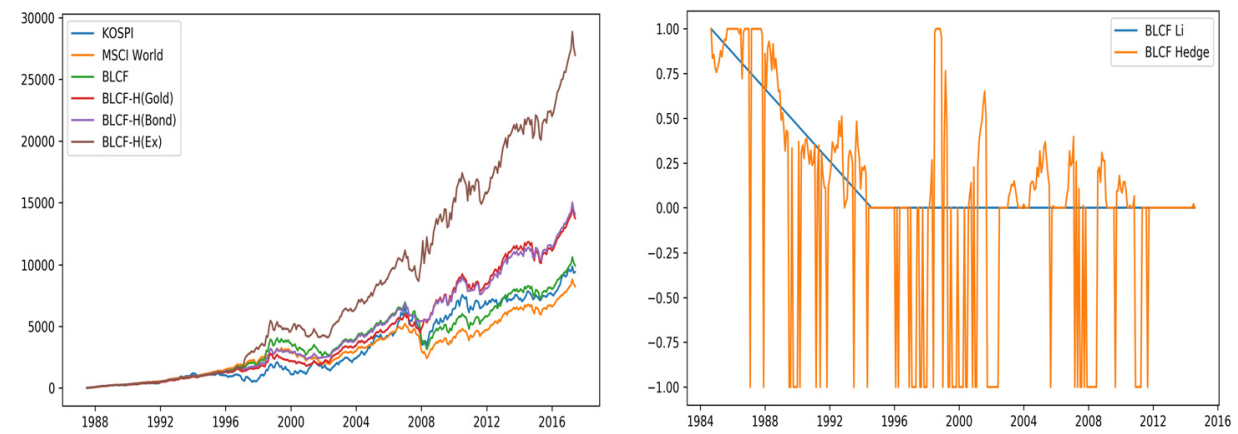

\section{Bootstrap을 이용한 BLCF 모형의 Robustness 검증}

본 장에서는 Bootstrap 방식을 이용하여 BLCF 모형의 Robustness를 검증한다. 일반적으로 Bootstrap 방식은 실제 데이터에서 무작위 복원추출방식으로 재표본 추출하는 방식이다. 그러나 본 논문의 전략은 주가지수의 모멘텀을 이용하는 방식으로 무작위 복원추출방식을 사용할 경우 데이터에서 모멘텀 효과를 모두 제거한다는 문제점이 있다. 이에 본 장에서는 데이터를 10 개월 단위로 무작위 복원추출하여, 재표본이 실제 데이터의 모멘텀을 일정부분 유지하도록 한다.

따라서 Bootstrap 방식은 다음과 같다. 먼저 1975.01.31 2018.05.31 기간 동안의 KOSPI, MSCI World 지수를 수익률로 변환한 후 10 개월 단위로 무작위 추출하여 재표본을 생성한다. 이 때 MSCI World 지수는 환노출의 가정하에서 수익률을 산출하였으며, 재표본의 길이는 본 데이터의 길이와 같도록 재표본을 생성한다. 다음으로 재표본을 이용하여 BLCF 전략을 
An Investment Strategy Based on Life and Business Cycles

이용, 수익률, 샤프지수, 확실성등가를 추출하여 전략의 유효성을 검증한다. $\mathrm{BLCF}$ 전략은 전환기간, 전환 후 투자기간을 각각 10년, 20 년으로 잡고, 9 개월 동안의 수익률 갭을 이용하여 경기국면변수를 만드는 방식으로 구성한다. 확실성등가의 경우, negative exponential utiliy function을 이용한다. 이러한 효용함수 하에서 확실성등가는 다음의 식으로 산출할 수 있다. 만큼의 위험 성향을 가지고 있는 소비자에게 있어, $N\left(\mu, \sigma^{2}\right)$ 을 따르는 수익률의 확실성등가(CE)는 다음과 같다.

$$
C E=\mu-(\lambda / 2) \times \sigma^{2}
$$

마지막으로 재표본 추출 및 모형 검증 과정을 10,000 회 반복하여 전략의 Robustness를 검증한다.

$<$ 그림 6>은 Bootstrap결과로 추출된 평균수익률과 샤프지수의 분포를, <표 9>는 Bootstrap 과로 추출된 평균 수익률과 샤프지수, 확실성 등가를 보여준다. Bootstrap 결과 평균수익률과 샤프지수의 평균값은 각각 $10.85 \%, 0.66$ 으로 나타났으며, Bootstrap 결과를 이용하여 확실성 등가를 추출하였을 때, 위험회피성향이 낮은 투자자 $(=1)$ 의 경우 $10.80 \%$ 의 수익률을, 위험회피성향이 극단적으로 높은 투자자 $(=100)$ 의 경우 $5.53 \%$ 의 수익률을 확실성등가로 가지는 것으로 나타났다.

$\mathrm{KOSPI}$ 를 벤치마크로 Bootstrap결과와 비교할 때, Bootstrap 평균수익률 및 샤프지수는 KOSPI보다 각각 약 $2.11 \%, 0.36$ 만큼 높다는 점에서 수익률은 높이고 변동성은 크게 낮추는 전략으로 여전히 유의함을 알 수 있다.

〈그림 6〉Bootstrap을 이용한 BLCF의 평균수익률(좌)과 샤프지수(우)의 분포 1975.01.31 2018.05.31 기간 동안의 KOSPI, MSCI World 지수 수익률을 10개월 단위로 무작위 추출하여 생성된 재표본을 바탕으로 $\mathrm{BLCF}$ 전략을 사용하여 도출된 수익률과 샤프지수의 히스토그램이다. 이 때, MSCI World 지수는 환노출의 가정하에서 수익률을 산출하였으며, 재표본의 길이는 본 데이터의 길이와 같도록 재표본을 생성하였다. BLCF 전략은 전환기간, 전환 후 투자기간을 각각 10 년, 20 년으로 잡고 9 개월 동안의 수익률 갭을 이용하여 경기국면변수를 만드는 방식으로 구성하였다. 이 때 경기국면변수의 계수는 본문과 같이 1 로 설정하였다. 재표본 추출 및 모형 검증과정은 총 10,000 회 반복하여 진행하였다.
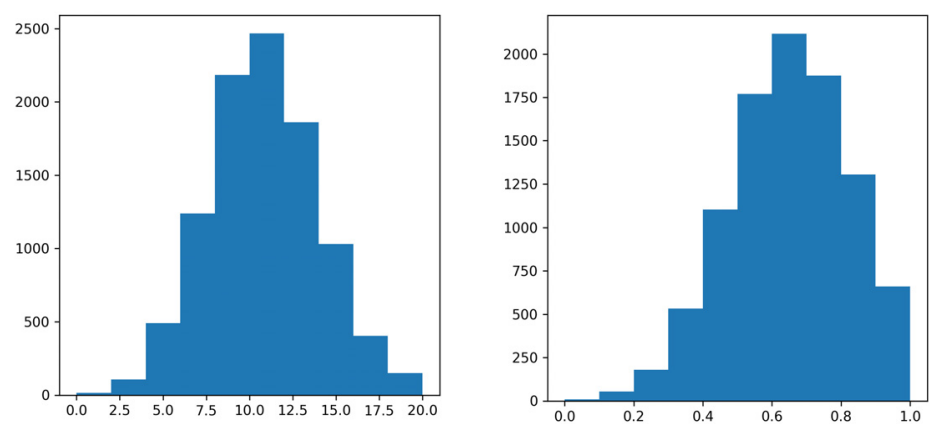

MSCI World 지수를 벤치마크로 Bootstrap 결과와 비교할 때, Bootstrap 평균수익률 및 샤프지수는 MSCI World_Ex보다 각각 약 $1.62 \%, 0.08$ 만큼 더 높다는 점에서 벤치마크 대비 매우 유의한 전략임을 알 수 있다. 
한국증권학회지 제48권 6호 (2019)

〈표 9〉Bootstrap을 이용한 BLCF의 평균수익률과 샤프지수의 분포 및 확실성 등가 패널 A는 1975.01.31 2018.05.31 기간 동안의 KOSPI, MSCI World 지수 수익률을 10개월 단위로 무작위 추출하여 생성된 재표본을 바탕으로 $\mathrm{BLCF}$ 전략을 사용하여 도출된 수익률과 샤프지수의 평균, 표준편차, 신뢰구간을 나타낸다. 이 때, MSCI World 지수는 환노출의 가정하에서 수익률을 산출하였으며, 재표본의 길이는 본 데이터의 길이와 같도록 재표본을 생성하였다. $\mathrm{BLCF}$ 전략은 전환기간, 전환 후 투자기간을 각각 10 년, 20 년으로 잡고 9 개월 동안의 수익률 갭을 이용하여 경기국면변수를 만드는 방식으로 구성하였다. 이 때 경기국면변수의 계수는 본문과 같이 1 로 설정하였다. 재표본 추출 및 모형 검증과정은 총 10,000 회 반복하여 진행하였다. 패널 $\mathrm{B}$ 는 10,000 회 반복하여 추출된 수익률과 샤프지수를 바탕으로 위험 성향에 따라 소비자가 가지는 확실성 등가를 나타낸다. 이 때, 소비자의 효용함수는 negative exponential utiliy function을 사용한다.

패널 A:평균수익률과 샤프지수의 평균값과 $95 \%$ 신뢰구간

\begin{tabular}{lccc}
\hline & 평균 & 표준편차 & $95 \%$ 신뢰구간 \\
\hline return & $10.85 \%$ & 0.0326 & {$[5.69 \%, 16.48 \%]$} \\
sharpe & 0.66 & 0.1890 & {$[0.35,0.98]$} \\
\hline
\end{tabular}

패널 $\mathrm{B}$ : 위험회피성향에 따른 확실성 등가

\begin{tabular}{cccccccc}
\hline & 1 & 2 & 3 & 5 & 8 & 10 & 100 \\
\hline $\mathrm{CE}$ & $10.80 \%$ & $10.75 \%$ & $10.69 \%$ & $10.59 \%$ & $10.43 \%$ & $10.32 \%$ & $5.53 \%$ \\
\hline
\end{tabular}

\section{8. 결론}

$\mathrm{TDF}$ 는 생애주기에 따라 투자자의 위험수용률이 변화한다는 점을 고려한 펀드로 미국 근로자의 약 $80 \%$ 가 은퇴를 대비하여 활용하는 상품이다. 최근 한국에서도 국민연금의 고갈에 대한 우려, 고령화로 인한 노후자산의 관리 문제가 대두되면서 $\mathrm{TDF}$ 가 주목받고 있다. 실제로 한국의 $\mathrm{TDF}$ 시장은 2017년 초 2천억 원 이하였으나, 2019년 현재 약 1조 5천억 원까지 성장하였으며 현재 퇴직연금에 대한 디폴트옵션으로서 $\mathrm{TDF}$ 를 고려하고 있다. 그러나 단순히 생애주기만을 이용한 $\mathrm{TDF}$ 는 시장상황에 탄력적으로 대응하지 못하며, 효과적인 노후자산 관리수단으로써 작용하기 어렵다. 이에 본 연구팀은 생애주기를 고려하여 투자를 진행하는 TDF를 바탕으로 시장상황을 고려하는 변수들을 추가하여 투자모형의 수익률을 개선하고 안정성을 확보하고자 하였다. 이는 한국의 퇴직연금 정책에서 디폴트옵션을 설정하는 데 있어 정책적 시사점을 제시하고 있다.

먼저 생애주기만을 고려한 $\mathrm{BLCF}-\mathrm{Li}$ 모형을 만들어 분석을 진행하였다. BLCF-Li 모형은 수익률과 샤프지수 측면에서 투자대상 지수인 KOSPI, MSCI World와 유의미한 차이를 만들어 내지 못하였다. 이는 생애주기만을 고려하였을 때 효과적인 수익률이 발생하지 않는다는 선행연구 들의 결과와 일치한다.

다음으로 생애주기에 더하여 시장 상황, 즉 경기순환주기를 투자모형에 고려하여 BLCF 모형을 만들고 이에 대한 분석을 진행하였다. 투자모형의 분석을 진행하기 이전에 본 연구는 모형의 정당성 및 최적시차에 관한 분석을 실시하였다. 정당성 분석을 통해 본 연구의 투자대상 지수인 KOSPI, MSCI World 지수는 서로 유사한 경기순환 주기를 가지며, 변동성의 차이가 
An Investment Strategy Based on Life and Business Cycles

존재함을 알 수 있었다. 다음으로 최적시차 분석을 통해 경기국면을 9 10개월로 파악할 때, 수익률을 극대화할 수 있음을 알 수 있었다. 투자결과, BLCF는 BLCF-Li, KOSPI, MSCI World와 비교하여 수익률 및 샤프지수가 명백하게 개선되었다. 그러나 투자 대상 자산이 모두 시장지수일 경우 전 세계적인 금융위기가 발생할 때 수익률의 하락을 피할 수 없다는 한계점이 있었다.

$\mathrm{BLCF}$ 모형의 한계점을 개선하기 위하여 생애주기와 경기순환주기에 경기침체판별변수를 추가적으로 고려하여 $\mathrm{BLCF}-\mathrm{H}$ 모형을 만들고, 이를 분석하였다. 그 결과 생애주기만 혹은 생애주기와 경기순환만을 고려하여 투자를 진행했을 때보다 글로벌리스크 헤지를 모형에 포함하였을 때 수익률과 샤프지수가 개선되었다. 따라서 생애주기, 경기순환주기, 경기침체 리스크를 모두 고려한 $\mathrm{BLCF}-\mathrm{H}$ 모형이 가장 좋은 투자결과를 얻을 수 있는 모형인 것으로 보이며 국민연금이나 기존 $\mathrm{TDF}$ 를 충분히 개선할 수 있을 것으로 보인다.

그러나 다른 자산에 대해서도 본 모형이 적용가능한지에 대한 추가적인 검토가 필요하다. 또한, 본 연구에서는 각 시장 지수 간의 수익률 차이가 $1 \%$ 일 때 비중을 $1 \% \mathrm{p}$ 이전하였는데 최적 민감도에 대한 추가 연구 역시 필요할 것으로 보인다. 


\section{References}

Arnott, R. D., K. F. Sherrerd, L. Wu, and G. Goyal, 2014, Practical Applications of The Glidepath Illusion... and Potential Solutions, The Journal of Portfolio Management, Practical Applications, Vol. 1 (4), pp. 6-9.

Appell, D., 2018, S. Korea's Target-Date Funds Get a Little Regulatory Help, Pensions \& Investments, Vol. 46 (19), p. 1.

Basu, A. K., A. Byrne, and M. E. Drew, 2011, Dynamic Lifecycle Strategies for Target Date Retirement Funds, Journal of Portfolio Management, Vol. 37 (2), pp. 83-96.

Booth, L., and B. Chang, 2011, The Global Financial Crisis and the Performance of Target-Date Funds in the United States, Rotman International Journal of Pension Management, Vol. 4 (2), pp. 46-52.

Branch, B., and L. Qui, 2011, Exploring the Pros and Cons of Target Date Funds, Financial Services Review, Vol. 20 (2), pp. 95-111.

Bredin, D., T. Conlon, and V. Potì, 2015, Does Gold Glitter in the Long-Run? Gold as a Hedge and Safe Haven Across Time and Investment Horizon, International Review of Financial Analysis, Vol. 41, pp. 320-328.

Byun, H., 2018, "Is National Pension Safe?" Rising Interest in TDF of 20s and 30s, (2018 September 8), Money Today.

Choi, W. S., 2018, Safe Haven Role of Gold on Stock: Mainly USA and Korea, The Korean Finance Association, 1998-2018.

Ciner, C., C. Gurdgiev, and B. M. Lucey, 2012, Hedges and Safe Havens: An Examination of Stocks, Bonds, Gold, Oil and Exchange Rates, International Review of Financial Analysis, Vol. 29, pp. 202-211.

Forsyth, P. A., Y. Li, and K. R. Vetzal, 2017, Are Target Date Funds Dinosaurs? Failure to Adapt can Led to Extinction, eprint arXiv:1705.00543.

Jang, I. H., 2018, Rising Concerns on National Pension Raising Interest to TDF, (2018. September 5), Asia Today.

Jeong, W. Y., 2008, Determinants of Portfolio Composition Choice: The Case of Korean Household, Financial Planning Review, Vol. 1 (1), pp. 81-108.

Kim, K. S., and K. H. Lee, 2012, A Study on the Contagion Effects among Stock Markets between Developed Countries and ASEAN, Korean Corporation Management Review, Vol. 19 (4), pp. 65-85.

Kim, B. D., 2017, Usage of Default Option in Pension Fund Management and Financial Enterprises, Weekley Financial Brief, Vol. 26 (5), pp. 3-7. 
An Investment Strategy Based on Life and Business Cycles

Kitchin, J., 1923, Cycles and Trends in Economic Factors, Review of Economics and Statistics, Vol. 5 (1), pp. 10-16.

Lee, J. H., 2016, A Study on the Performance of Dynamic Strategic Asset Allocation Under the Regime Shifts, Journal of Finance \& Knowledge Studies, Vol. 14 (2), pp. 145-170.

Pang and Warshawsky, 2011, Target-Date and Balanced Funds: Latest Market Offerings and Risk-Return Analysis, Financial Services Review, Vol. 20 (1), pp. 21-24.

Spitzer and Singh, 2008, Shortfall Risk of Target-date Funds During Retirement, Business ${ }^{-}$ Economics Faculty Publications, Vol. 17 (2), pp. 143-153.

Spitzer and Singh, 2011, Assessing the Effectiveness of Lifecycle(Target-Date) Funds during the Accumulation Phase, Financial Services Review, Vol. 20 (4), pp. 327-341.

Yoon, Y., 2010, Glide Path and Dynamic Asset Allocation of Target Date Funds, Journal of Asset Management, Vol. 11 (5), pp. 346-360.

Yuh, Y. K., and S. H. Joung, 2004, Determinants of Households' Stock Investments, Journal of Korean Management Association, Vol. 22 (3), pp. 11-21. 


\section{〈Appendix I〉 GDP as a Business Cycle Variable(BLCF-GDP)}

경기국면을 파악하는데 있어 본 연구에서는 금융변수인 주가지수를 이용하였으나, 이 외에도 $\mathrm{GDP}$ 등 실물변수를 사용할 수도 있고 금리와 같은 화폐 변수를 사용할 수도 있다. 그러나 금리는 신흥시장의 데이터가 충분히 축적되지 않았다는 점에서 현재 사용하기 어렵다. 따라서 본 부록에서는 신흥시장과 글로벌시장의 $\mathrm{GDP}$ 성장률 갭을 이용하여 경기국면변수를 만들고, 데이터를 도출하여 분석하였다. 경기국면변수 이외에는 본문의 $\mathrm{BLCF}$ 와 동일한 조건으로 분석을 진행하였다.

경기국면변수

$$
\mathrm{Gap}_{t}=\prod_{i=1}^{n} \operatorname{growth}_{E M, t-i}-\prod_{i=1}^{n} \operatorname{growth}_{G M, t-i}
$$

$\mathrm{GDP}$ 성장률 갭을 이용하여 만든 경기국면변수를 바탕으로 $\mathrm{BLCF}$ 를 설계할 경우, 최적시차는 6 개월인 것으로 나타났다. $\mathrm{GDP}$ 성장률 갭을 이용한 $\mathrm{BLCF}-\mathrm{GDP}$ 와 경기국면변수를 완전히 제거한 BLCF-Li 모형은 유사한 수익률을 보이며, 지수수익률 갭을 이용한 BLCF에 비해서는 수익률과 샤프지수 모두에서 절대적 열위에 있다. 이를 통해 GDP 성장률 갭을 이용한 경기국면 변수는 유의미하지 않다는 결론을 도출할 수 있다.

〈표 A1〉 환노출을 가정하였을 때의 GDP를 이용한 BLCF 모형과 일반 BLCF 모형 $<$ 표 4>와 동일하게 투자기간에 따른 BLCF Ex의 수익률 및 샤프지수를 도출하였다. 그러나 <표 $4>$ 는 누적수익률의 갭에 근거하여 경기국면을 파악한 반면 <표 $\mathrm{A} 1>$ 은 $\mathrm{GDP}$ 의 성장률 갭을 이용하여 경기국면을 파악하였다는 차이가 있다. 환노출 상황을 가정하였기 때문에 MSCI World의 지수 수익률에 환율 변화율을 더하여 산출하였다. BLCF 모형은 두 가지의 투자전략으로 이루어져 있다. 첫 번째는 시간에 따라 신흥시장에서 글로벌 시장 지수로 투자비중을 이전하는 전략이다. 이 전략은 전환기간(P1)과 전환 후 투자기간(P2)에 의하여 투자비중의 이전속도가 변화한다는 특징이 있다. 전환기간이란 시간에 따라 투자비중을 신흥시장에서 글로벌시장으로 전환하는 기간을 의미하며, 초기에는 신흥시장 지수에 전액 투자하되, 전환기간 동안 글로벌시장 지수로 투자비중을 동일비중 이전한다. 경기국면에 변화가 없는 한, 전환기간의 종료시점에는 글로벌시장 지수로 투자비중이 전액 투자된다. 전환 후 투자기간동안은 경기국면에 변화가 없는 한, 글로벌시장 지수로 전액 투자한 상태로 투자를 유지하는 기간을 의미한다. 두 번째는 경기국면에 따라 투자비중을 이전하는 방식이다. 이 전략에 따르면 신흥시장의 $\mathrm{n}$ 개월 동안의 누적수익률 혹은 $\mathrm{GDP}$ 성장률 간의 차이가 $1 \% \mathrm{p}$ 증가할 때마다 포트폴리오의 비중을 신흥시장으로 $1 \% \mathrm{p}$ 이전하며, 반대로 글로벌시장의 $\mathrm{n}$ 개월 누적수익률 혹은 $\mathrm{GDP}$ 성장률 간의 차이가 $1 \% \mathrm{p}$ 증가할 때마다 포트폴리오의 비중을 글로벌시장으로 $1 \% \mathrm{p}$ 이전한다. <표 $\mathrm{A} 1>$ 의 각 행은 전환기간(P1)과 전환 후 투자기간 (P2)에 따른 결과값이며 1 4열은 최근 $\mathrm{n}$ 개월 동안의 신흥시장과 글로벌 시장의 GDP 성장률 차이를 이용하여 격기국면을 파악한 모형의 결과값이다. $\mathrm{GDP}$ 의 산출기간이 분가 단위인 만큼 시차는 3 개월 단위로 나타내었다. 또한 비교를 위하여 5열과 6열에는 환 노출을 가정한 BLCF 모형인 BLCF Ex모형과 환노출을 가정한 BLCF- Li 모형인 BLCF-Li Ex모형을 각각 추가하였다. 투자시작시점에 따라 투자결과가 다르게 도출될 수 있다는 점을 감안하여 총 투자기간이 20년, 25년, 30년, 35년, 40년일 때 각각 1975.01 .31 1998.05.31, 1975.01.31 1993.05.31, 1975.01.31 1988.05.31, 1975.01.31 1983.05.31, 1975.01.31 1978.05.31을 투자시작시점으로 하여 결과를 도출하고 이 결과들의 평균치를 기록하였다. 투자수익률의 경우 수익률을 연율화하였다. 괄호 밖의 데이터는 연 단위 투자수익률을 괄호 안의 데이터는 샤프지수를 나타낸다. 
An Investment Strategy Based on Life and Business Cycles

〈표 A1〉 환노출을 가정하였을 때의 GDP를 이용한 BLCF 모형과 일반 BLCF 모형(계속)

\begin{tabular}{ccccccc}
\hline $\mathrm{n}$ & 3 & $6^{*}$ & 9 & 12 & BLCF Ex $^{*}$ & BLCF-Li Ex \\
\hline \multirow{2}{*}{$10 \_10$} & $8.75 \%$ & $8.84 \%$ & $8.62 \%$ & $8.73 \%$ & $12.79 \%$ & $8.90 \%$ \\
& $(0.522)$ & $(0.529)$ & $(0.505)$ & $(0.514)$ & $(0.692)$ & $(0.531)$ \\
$10 \_15$ & $9.00 \%$ & $9.11 \%$ & $8.85 \%$ & $8.98 \%$ & $12.56 \%$ & $9.23 \%$ \\
& $(0.549)$ & $(0.559)$ & $(0.532)$ & $(0.541)$ & $(0.689)$ & $(0.562)$ \\
$15 \_10$ & $8.93 \%$ & $8.98 \%$ & $8.67 \%$ & $8.75 \%$ & $12.71 \%$ & $9.10 \%$ \\
& $(0.526)$ & $(0.529)$ & $(0.501)$ & $(0.507)$ & $(0.669)$ & $(0.536)$ \\
$10 \_20$ & $9.42 \%$ & $9.63 \%$ & $9.46 \%$ & $9.70 \%$ & $12.66 \%$ & $9.65 \%$ \\
& $(0.593)$ & $(0.610)$ & $(0.587)$ & $(0.604)$ & $(0.719)$ & $(0.605)$ \\
$15 \_15$ & $9.47 \%$ & $9.64 \%$ & $9.41 \%$ & $9.59 \%$ & $12.87 \%$ & $9.63 \%$ \\
& $(0.582)$ & $(0.594)$ & $(0.568)$ & $(0.581)$ & $(0.707)$ & $(0.591)$ \\
$20 \_10$ & $9.29 \%$ & $9.38 \%$ & $9.09 \%$ & $9.20 \%$ & $12.90 \%$ & $9.38 \%$ \\
& $(0.550)$ & $(0.555)$ & $(0.529)$ & $(0.537)$ & $(0.685)$ & $(0.557)$ \\
$15 \_20$ & $9.07 \%$ & $9.30 \%$ & $9.18 \%$ & $9.45 \%$ & $12.24 \%$ & $9.34 \%$ \\
& $(0.587)$ & $(0.605)$ & $(0.586)$ & $(0.604)$ & $(0.709)$ & $(0.602)$ \\
$20 \_15$ & $8.98 \%$ & $9.16 \%$ & $8.96 \%$ & $9.14 \%$ & $12.31 \%$ & $9.17 \%$ \\
& $(0.567)$ & $(0.579)$ & $(0.556)$ & $(0.569)$ & $(0.692)$ & $(0.579)$ \\
$20 \_20$ & $8.82 \%$ & $8.97 \%$ & $8.83 \%$ & $9.15 \%$ & $11.68 \%$ & $9.17 \%$ \\
& $(0.588)$ & $(0.601)$ & $(0.581)$ & $(0.604)$ & $(0.700)$ & $(0.611)$ \\
\hline
\end{tabular}

\section{〈Appendix II〉 투자전략의 모수 최적화}

\section{1. 시간에 따른 투자 비중의 조정 방식 최적화}

본 장에서는 투자비중의 조정에 있어 경기국면변수의 영향력을 크게 만들었을 때의 변화를 관찰, 경기국면변수를 최적화해보고자 한다. 본문의 경우, 경기국면변수의 계수를 1 로 두어 신흥시장 지수 수익률이 글로벌 시장의 수익률에 비해 $1 \% \mathrm{p}$ 높을 때마다 신흥시장으로 투자비중을 $1 \% \mathrm{p}$ 이전하도록 설정하였는데, 이는 연금펀드의 규모가 커서 비중변화가 극심할 경우 슬리피지가 생길 가능성이 높고 시장을 왜곡시킬 가능성이 크기 때문이다. 그러나 본 장에서는 다른 요소는 고려하지 않고, 오직 수익률과 샤프지수의 관점에서 경기국면변수의 계수를 최적화한다.

데이터는 본문에서와 같이 1975.01.31 2018.05.31 기간 동안의 KOSPI와 MSCI World 단일지수를 각각 신흥시장 지수와 글로벌시장 지수로 이용하였으며, MSCI World 단일지수는 환노출의 상황을 가정하였다. 또한 BLCF 모형을 사용함에 있어, 본문과 같이 전환기간, 전환 후 투자기간을 각각 10 년, 20 년으로 두고 경기국면변수의 시차를 9 개월로 설정하였다. 경기국면 변수의 계수를 $\operatorname{alpha}(\alpha)$ 로 두면, 시간의 변화에 따른 투자비중의 변화는 다음과 같다.

경기국면변수

$$
\operatorname{Gap}_{t}=\prod_{i=1}^{n} \operatorname{Ret}_{E M, t-i}-\prod_{i=1}^{n} \operatorname{Ret}_{G M, t-i}
$$


시간(t)의 변화에 따른 투자비중 $(\mathrm{W})$ 변화

$$
\begin{aligned}
& t=0, \quad\left(W_{E M}, W_{G M}\right)=(1,0) \\
& 0<t \leq P_{1}, \quad\left(W_{E M}, W_{G M}\right)=\left(1-\frac{t}{P_{1}}+\alpha \times G a p_{t}, 0+\frac{t}{P_{1}}-\alpha \times G a p_{t}\right) \\
& P_{1}<t \leq P_{2}, \quad\left(W_{E M}, W_{G M}\right)=\left(G a p_{t}, 1-G a p_{t}\right) \\
& \text { 단, } W_{E M}\left(\text { or } W_{G M}\right)<0 \text { 이면, } W_{E M}\left(\text { or } W_{G M}\right)=0, \\
& W_{E M}\left(\text { or } W_{G M}\right)>1 \text { 이면, } W_{E M}\left(\text { or } W_{G M}\right)=1
\end{aligned}
$$

alpha를 0에서 100까지 조정할 때, 수익률과 샤프지수의 변화는 다음의 <그림 A1>과 같다. alpha가 0 인 경우, 즉 경기국면을 고려하지 않는 $\mathrm{TDF}$ 전략의 경우 수익률과 샤프지수가 각각 $9.57 \%, 0.60$ 으로 전략의 성과가 가장 부진하였으며, alpha가 100 인 경우, 즉 경기국면에 따라 극단적으로 비중을 조정한 경우 수익률과 샤프지수가 $18.06 \%, 0.84$ 로 가장 성과가 높게 나타났다. 이러한 결과는 다음의 두 가지 함의를 가진다. 먼저 시장상황을 고려한 투자는 투자성과를 개선시킬 수 있다. $\mathrm{TDF}$ 는 근로자의 생애주기에 최적화한 펀드로써 투자자에게 친화적이나 시장상황을 고려하는 데에 취약하다. 따라서 경기국면변수를 도입함으로써 $\mathrm{TDF}$ 를 강화시킬 수 있다. 다음으로 경기국면, 즉 시장을 고려하면 고려할수록 평균수익률의 증가와 이로인한 샤프지수의 증가가 발생한다. 따라서 평균수익률과 샤프지수를 극대화하기 위해서는 경기국면에 의해 비중을 완전히 변화시키는 방법, 즉 한 지수에 $100 \%$ 의 비중으로 투자하여야 한다.

〈그림 A1〉 경기국면변수 계수 변화에 따른 평균수익률(좌)과 샤프지수(우)의 변화 1975.01.31 2018.05.31 기간 동안 경기국면변수(alpha)의 변화에 따른 BLCF Ex의 수익률 및 샤프지수을 도출한 데이터이다. $\mathrm{BLCF} \mathrm{Ex}$ 란 환노출의 가정 하에서 $\mathrm{BLCF}$ 모델의 투자전략을 진행한 모델을 의미한다. 환노출의 가정이므로 MSCI World 지수의 수익률은 지수변화율에 환율 변화율을 더하여 산출하였다. $\mathrm{BLCF}$ 모델을 진행함에 있어 본문에서와 같이 전환기간을 10 년, 전환 후 투자기간을 20 년으로 두고 경기국면변수의 시차는 9 개월로 설정하였다.
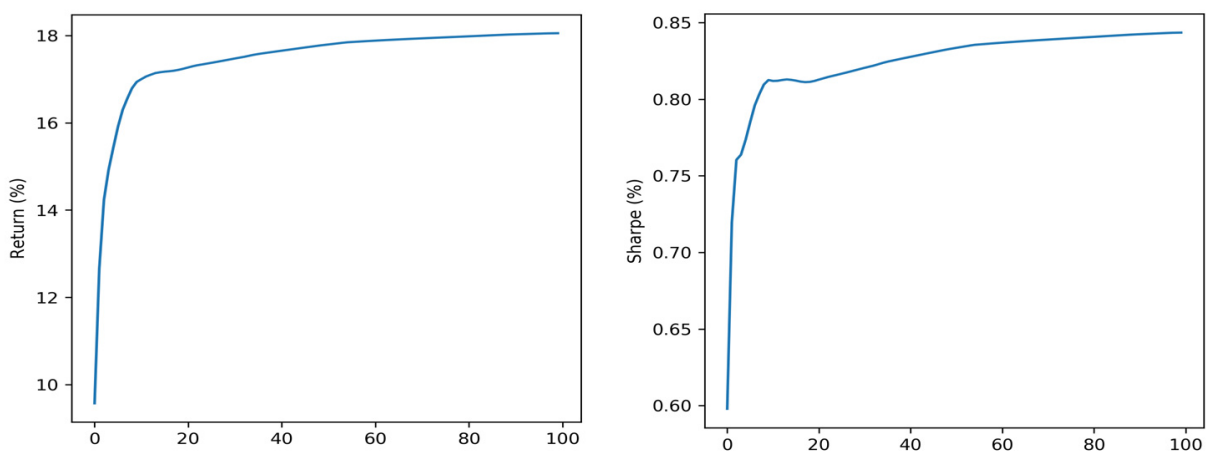

다만, 경기국면변수의 계수를 늘리는 것은 거래비용 및 슬리피지, 대규모 자금이동에 대한 금융당국의 규제 등으로 인하여 현실적으로 어려울 수 있으며, Target-Dated Fund의 성격을 
An Investment Strategy Based on Life and Business Cycles

희석시킬 수 있다. 따라서 평균수익률과 샤프지수보다는 현실적 측면에서 alpha를 선택하는 것이 최선일 수 있다.

\section{2. 경기침체 판별변수(RS)의 경계값 최적화}

본 장에서는 투자비중의 조정에 있어 경기침체 판별변수(RS)의 영향력을 크게 만들었을 때의 변화를 관찰, 최적화해보고자 한다. 본문의 경우, 신흥시장 지수와 글로벌 시장 지수의 6 개월 누적 수익률 합이 $-20 \%$ 이하일 때, 경기침체의 징후로 간주하도록 설정하였다. 본 장에서는 경기침체 판별변수로 다른 요소는 고려하지 않고, 오직 수익률과 샤프지수의 관점에서 경기침체 판별변수의 계수를 최적화한다.

데이터는 본문에서와 같이 1975.01.31 2018.05.31 기간 동안의 KOSPI와 MSCI World 단일지수를 각각 신흥시장 지수와 글로벌시장 지수로, 헤지수단으로 금, 원/달러 환율, 미 국채를 이용하였다. 이 때 MSCI World 단일지수, 미 국채는 환율과의 비교를 위하여 환헤지의 상황을 가정하였다. 또한 $\mathrm{BLCF}-\mathrm{H}$ 모형을 사용함에 있어, 본문과 같이 전환기간, 전환 후 투자기간을 각각 10 년, 20 년으로 두고 경기국면변수의 시차를 9 개월로, 경기국면변수의 계수를 1 로 설정하였다.

〈그림 A2〉 경기침체 판별변수의 변화에 따른 수익률(좌)과 샤프지수(우)

1975.01.31 2018.05.31 기간 동안 경기침체판별변수의 계수 변화에 따른 BLCF의 수익률 및 샤프지수를 도출한 데이터이다. 미 달러의 헤지효과를 다른 자산들과 비교하기 위하여 미 달러에 투자하는 전략을 제외한 모든 투자에 있어서 환율 변동을 전혀 고려하지 않았다. No safe Asset의 경우, 경기침체가 예상될 때, 어떤 자산에도 투자하지 않는 경우의 수익률 및 샤프지수를 나타낸다.
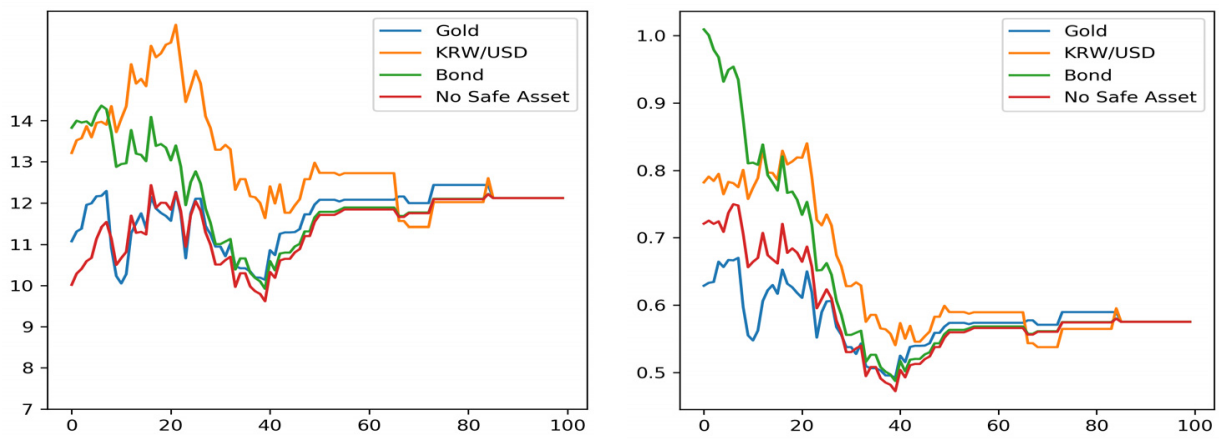

<그림 A2>는 경기침체 판별변수가 $-0 \sim 100 \%$ 로 변화함에 따라 안전자산 혹은 안전자산이 없을 때의 수익률과 샤프지수를 나타낸다. <그림 A1>에서, 안전자산에 투자하지 않더라도 경기침체 판별변수를 활용함으로써 샤프지수를 증가시킬 수 있음을 알 수 있다. 또한 경기침체 판별변수가 약 $-20 \%$ 인 경우, 수익률과 샤프지수가 극대화되는 것을 알 수 있다. 이는 다음의 시사점을 가진다. 먼저 경기침체 판별변수의 계수가 클수록, 경기침체 상황에 대해 늦게 반응하는 반면, 경기호황을 불황으로 오인할 가능성이 줄어든다. 반대로 경기침체 판별변수의 계수가 작을수록 경기상황에 대해 빠르게 반응할 수 있지만, 호황을 불황이라고 오인할 가능성이 높다. 


\section{3. 전환기간, 전환 후 투자기간의 설정}

본 장에서는 투자비중의 조정을 조정함에 있어, 전환기간과 전환 후 투자기간의 비중을 최적화하고자 한다. 본문에서는 분석의 편의를 위해 투자기간을 5 년단위로 나누어 분석하였으나, 본 장에서는 총 투자기간 및 전환기간, 전환 후 투자기간을 세분화하여 전환기간과 전환 후 투자기간의 비중을 최적화한다.

데이터는 본문에서와 같이 1975.01.31 2018.05.31 기간 동안의 KOSPI와 MSCI World 단일지수를 각각 신흥시장 지수와 글로벌시장 지수로 이용하였으며, MSCI World 단일지수는 환노출의 상황을 가정하였다. 또한 BLCF 모형을 사용함에 있어, 본문과 같이 경기국면변수의 시차를 9 개월로, 경기국면변수의 계수를 1 로 설정하였다.

$<$ 그림 $\mathrm{A} 3>$ 를 보면 총 투자기간에 관계없이 전환기간(P1)의 조정은 수익률과 안정성에 대한 선택의 문제로 귀결된다. 전환기간을 증가시킬 때, 수익률은 증가하는 경향이 있는 반면, 샤프 지수는 감소하는 경향이 있다. 따라서 전환기간 및 전환 후 투자기간에 대한 비중 선택은 특정한 정답이 존재 한다기보다, 투자자의 선호 및 위험성향에 따라 선택적으로 변화되어야 한다.

\section{〈그림 A3〉 투자기간에 따른 수익률과 샤프지수}

패널 A는 1975.01.31 2018.05.31 기간 동안 총 투자기간을 21 30년일 때, 전환기간의 변화에 따른 $\mathrm{BLCF} \mathrm{Ex}$ 수익률과 샤프지수를 나타낸다. BLCF Ex란 환노출의 가정 하에서 BLCF 모델의 투자전략을 진행한 모델을 의미한다. 환노출의 가정이므로 MSCI World 지수의 수익률은 지수변화율에 환율 변화율을 더하여 산출하였다. 가령 총 투자기간이 21 년일 때, 전환기간을 0 에서 20 년까지 변화시키면서 수익률과 샤프지수를 나타내었다. 패널 $\mathrm{B}$ 는 총 투자기간을 $31 \sim 40$ 년일 때, 전환기간의 변화에 따른 $\mathrm{BLCF} \mathrm{Ex}$ 수익률과 샤프지수를 나타낸다.

패널 A: 투자기간이 21 30년 일 때, 전환기간에 따른 수익률(좌)과 샤프지수(우)
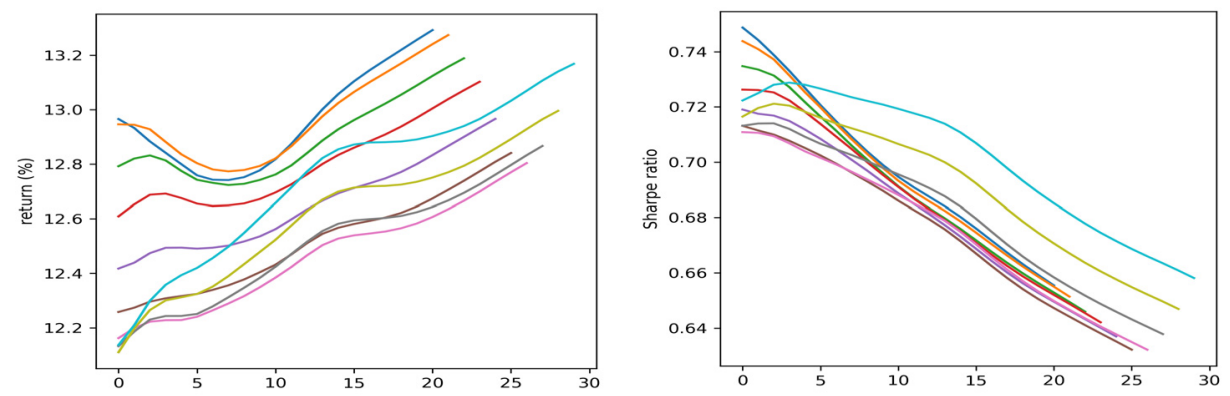

패널 B: 투자기간이 31 40년 일 때, 전환기간에 따른 수익률(좌)과 샤프지수(우)
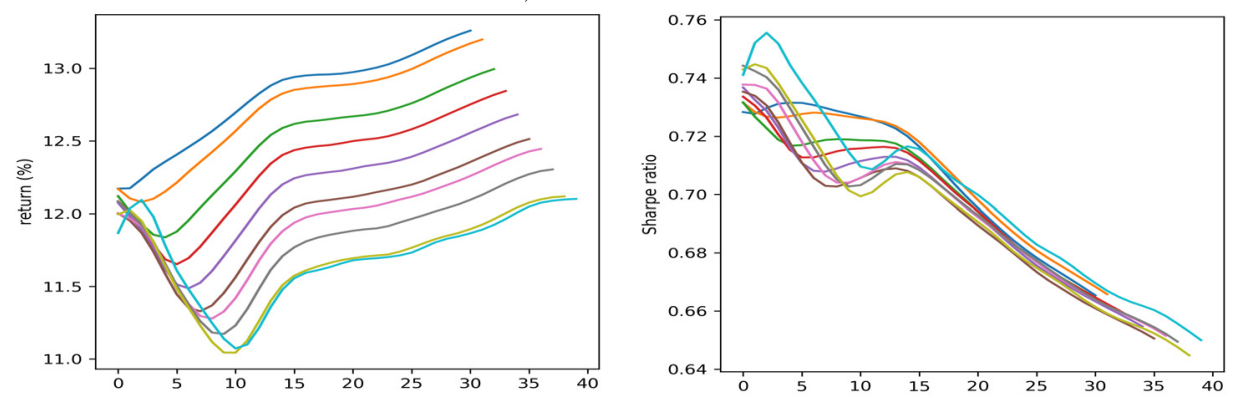


\section{〈Appendix III〉 문헌조사}

\begin{tabular}{|c|c|c|c|}
\hline 저자(연도) & 연구문제 & 주요 결론 & 본 연구와의 관계 \\
\hline $\begin{array}{l}\text { Yuh and } \\
\text { Joung } \\
\text { (2004) }\end{array}$ & $\begin{array}{l}\text { 개인의 자본투자에 영향 } \\
\text { 을 미치는 요소는 무엇 } \\
\text { 인가? }\end{array}$ & $\begin{array}{l}\text { 자본투자에 영향을 미치는 요 } \\
\text { 소는 나이를 포함한 다수가 } \\
\text { 있다. }\end{array}$ & $\begin{array}{c}\text { 나이는 확실히 개인의 투자 } \\
\text { 성향에 영향을 미친다. }\end{array}$ \\
\hline Jeong(2008) & $\begin{array}{l}\text { 가계의 자산투자에 영향 } \\
\text { 을 미치는 요소는 무엇 } \\
\text { 인가? }\end{array}$ & $\begin{array}{l}\text { 교육, 연간 수입, 나이 등이 가 } \\
\text { 계의 포트폴리오에 대해 유 } \\
\text { 의한 요소이다. }\end{array}$ & $\begin{array}{l}\text { 가계에서 가장의 나이가 증가 } \\
\text { 할수록 안전자산을 선호 } \\
\text { 한다. }\end{array}$ \\
\hline $\begin{array}{l}\text { Arnott et al. } \\
(2014)\end{array}$ & $\begin{array}{l}\text { 글라이드패스에 따라 } \\
\text { 투자하는 것이 최선인가? }\end{array}$ & $\begin{array}{l}\text { 글라이드패스 투자전략은 밸 } \\
\text { 런스펀드나 역글라이드 패 } \\
\text { 스 전략보다 좋지 않은 성과 } \\
\text { 를 도출한다. }\end{array}$ & $\begin{array}{l}\mathrm{TDF} \text { 는 기존의 글라이드패스 } \\
\text { 처럼 시간에만 영향을 받기 } \\
\text { 보다 시황에 따라 변화해야 } \\
\text { 한다. }\end{array}$ \\
\hline $\begin{array}{l}\text { Basu et al. } \\
\text { (2011) }\end{array}$ & $\begin{array}{l}\text { TDF에서 가입시 정해진 } \\
\text { 비중조절 규칙을 유지 } \\
\text { 하는 것이 효과적인가? } \\
\text { 만약 그렇지 않다면 어 } \\
\text { 떤 전략으로 대신할 수 } \\
\text { 있는가? }\end{array}$ & $\begin{array}{l}\text { 생애주기에만 근거하는 전통 } \\
\text { 적인 투자방식은 충분하지 않 } \\
\text { 다. 계속 시황을 확인하는 작 } \\
\text { 업이 필요하다. }\end{array}$ & $\begin{array}{l}\text { 이전 시기의 성과를 고려하여 } \\
\text { 동적으로 비중조절을 실시 } \\
\text { 해야 한다. }\end{array}$ \\
\hline $\begin{array}{l}\text { Booth and } \\
\text { Chang } \\
\text { (2011) }\end{array}$ & $\begin{array}{l}\text { 2008년 금융위기 때 TDF } \\
\text { 의 성과는 어땠는가? }\end{array}$ & $\begin{array}{l}\mathrm{TDF} \text { 는 주식들보다는 좋은 성 } \\
\text { 과를 보였으나 동적 비중조 } \\
\text { 정을 통하여 성과를 개선할 } \\
\text { 수 있다. }\end{array}$ & $\begin{array}{l}\mathrm{TDF} \text { 는 시황에 맞추어 동적 } \\
\text { 으로 반응할 수 있어야 한다. }\end{array}$ \\
\hline $\begin{array}{r}\text { Branch and } \\
\text { Qui(2011) }\end{array}$ & $\begin{array}{l}\text { TDF방식의 투자가 } \\
\text { 최선인가? }\end{array}$ & $\begin{array}{l}\text { 주식에 높은 비율로 장기투자 } \\
\text { 를 할 경우에 더 높은 샤프비 } \\
\text { 율과 트레이너 비율을 얻을 } \\
\text { 수 있다. 따라서 } \mathrm{TDF} \text { 가 최 } \\
\text { 선은 아니다. }\end{array}$ & $\begin{array}{l}\text { 전통적인 } \mathrm{TDF} \text { 는 충분한 } \\
\text { 성과를 보이지 못한다. }\end{array}$ \\
\hline $\begin{array}{l}\text { Forsyth et al. } \\
\quad(2017)\end{array}$ & TDF가 변화해야 하는가? & $\begin{array}{l}\text { 선형 글라이드패스를 가진 } \\
\mathrm{TDF} \text { 나 밸런스드 펀드는 충 } \\
\text { 분한 성과를 보이지 못한다. }\end{array}$ & $\begin{array}{c}\text { 투자 시작 전에 결정된 선형 } \\
\text { 글라이드패스는 유효하지 } \\
\text { 않다. 따라서 TDF의 비중조 } \\
\text { 절 전략은 개선이 필요하다. }\end{array}$ \\
\hline $\begin{array}{l}\text { Spitzer and } \\
\text { Singh } \\
(2008)\end{array}$ & TDF는 유효한가? & $\begin{array}{l}\mathrm{TDF} \text { 는 충분한 성과를 내지 } \\
\text { 못할 가능성이 높으므로 } \\
\mathrm{TDF} \text { 전략을 사용하는 것에 } \\
\text { 대해서 재고할 필요가 있다. }\end{array}$ & $\begin{array}{l}\text { 전통적인 TDF는 개선의 필요 } \\
\text { 성이 있다. }\end{array}$ \\
\hline $\begin{array}{l}\text { Spitzer and } \\
\text { Singh } \\
(2011)\end{array}$ & $\begin{array}{l}\text { 상승기에도 } \mathrm{TDF} \text { 가 유효 } \\
\text { 한가? }\end{array}$ & $\begin{array}{l}\text { 상승기의 경우 } \mathrm{TDF} \text { 는 좋은 } \\
\text { 성과를 보이지 못한다. 그러 } \\
\text { 나 이전 성과에 맞추어 적응 } \\
\text { 적인 전략을 사용할 경우 성 } \\
\text { 과가 개선된다. }\end{array}$ & $\begin{array}{l}\text { 생애주기만을 사용하여 } \mathrm{TDF} \text { 를 } \\
\text { 만들 경우 다른 펀드보다 낮 } \\
\text { 은 성과를 보인다. 따라서 적 } \\
\text { 응적 전략을 통하여 개선의 } \\
\text { 필요성이 있다. }\end{array}$ \\
\hline $\begin{array}{l}\text { Pang and } \\
\text { Warsha } \\
\text { wsky } \\
(2011)\end{array}$ & $\begin{array}{l}\text { TDF전략의 의의는 } \\
\text { 무엇인가? }\end{array}$ & $\begin{array}{l}\text { 투자자가 은퇴에 가까워질수 } \\
\text { 록 TDF는 밸런스드 펀드 } \\
\text { 보다 위험성이 감소한다. 그 } \\
\text { 러나 수익률의 측면에서는 } \\
\text { 부족한 측면이 있다. }\end{array}$ & TDF의 수익률이 너무 낮다. \\
\hline
\end{tabular}


한국증권학회지 제48권 6호 (2019)

\begin{tabular}{|c|c|c|c|}
\hline 저자(연도) & 연구문제 & 주요 결론 & 본 연구와의 관계 \\
\hline Yoon(2010) & $\begin{array}{l}\mathrm{TDF} \text { 는 어떻게 개선할 수 } \\
\text { 있는가? }\end{array}$ & $\begin{array}{l}\text { 전통적인 TDF는 시간의 변화 } \\
\text { 에 따른 위험의 변화를 고려 } \\
\text { 하지 않는다. 위험의 변화를 } \\
\text { 고려하게 되면 투자결과가 } \\
\text { 개선된다. }\end{array}$ & $\begin{array}{c}\mathrm{TDF} \text { 는 시간에 따른 위험의 } \\
\text { 변화를 고려해야한다. }\end{array}$ \\
\hline Lee(2016) & $\begin{array}{l}\text { 경기변동을 고려하는 동 } \\
\text { 적 투자방식은 정적 투 } \\
\text { 자방식보다 좋은 성과 } \\
\text { 를 보이는가? }\end{array}$ & $\begin{array}{l}\mathrm{MSM} \text { 에 근거한 동적 투자 } \\
\text { 방식은 정적 투자전략보다 } \\
\text { 좋은 성과를 보였다. }\end{array}$ & $\begin{array}{c}\text { 경기변동을 고려하면 투자성 } \\
\text { 과가 더 좋아질 수 있다. }\end{array}$ \\
\hline $\operatorname{Kim}(2017)$ & $\begin{array}{l}\mathrm{TDF} \text { 가 연금펀드의 디폴 } \\
\text { 트옵션으로서 충분한 } \\
\text { 가? }\end{array}$ & $\begin{array}{l}\text { 알맞은 자산의 선택과 시황에 } \\
\text { 대해서도 고려한다면 TDF } \\
\text { 는 개선될 수 있으며 디폴트 } \\
\text { 옵션으로 적절할 수 있다. } \\
\text { 한국시장만이 아닌 해외시 } \\
\text { 장을 포트폴리오에 포함할 } \\
\text { 경우 더 좋은 성과를 보였다. }\end{array}$ & $\begin{array}{l}\text { 해외시장에 대한 투자가 더 } \\
\text { 좋은 결과를 도출할 수 있 } \\
\text { 으며 시황에 대한 고려도 } \\
\text { 포함되어야 한다. }\end{array}$ \\
\hline $\begin{array}{l}\text { Kim and Lee } \\
\text { (2012) }\end{array}$ & $\begin{array}{l}\text { 금융위기 이후 선진국과 } \\
\text { 개발도상국 시장의 상 } \\
\text { 관관계가 높아졌는가? }\end{array}$ & $\begin{array}{r}\text { 세계적인 금융위기 이후 아세 } \\
\text { 안국가와 세계시장 간의 상 } \\
\text { 관관계가 증가하였으며 서 } \\
\text { 로 간의 연결성도 높아졌다. }\end{array}$ & $\begin{array}{l}\text { 세계 금융시장과 개발도상국 } \\
\text { 사이의 상관관계가 높아 } \\
\text { 졌으므로 위험관리의 중 } \\
\text { 요성이 높아졌다고 할 수 } \\
\text { 있다. }\end{array}$ \\
\hline $\begin{array}{l}\text { Bredin et al. } \\
\quad(2015)\end{array}$ & $\begin{array}{l}\text { 금은 헤징을 위한 자산으 } \\
\text { 로 사용될 수 있는가? }\end{array}$ & $\begin{array}{l}\text { 금은 지속적으로 헤징수단 } \\
\text { 으로 유효하다. }\end{array}$ & $\begin{array}{c}\mathrm{BLCF} \text { 의 설계에 있어 금을 } \\
\text { 헤징수단으로 사용하는 } \\
\text { 것은 유효한 방법이다. }\end{array}$ \\
\hline $\begin{array}{l}\text { Ciner et al. } \\
\quad(2012)\end{array}$ & $\begin{array}{r}\text { 헤징을 위해서는 어떤 자 } \\
\text { 산을 사용할 수 있는가? }\end{array}$ & $\begin{array}{l}\text { 금과 채권은 주식시장에 대한 } \\
\text { 헤징 수단으로 사용될 수 } \\
\text { 있다. }\end{array}$ & $\begin{array}{l}\text { 채권과 금은 주식에 대해서 } \\
\text { 헤징수단으로 사용될 수 } \\
\text { 있다. }\end{array}$ \\
\hline Choi(2018) & $\begin{array}{l}\text { 미국과 한국시장에서 금 } \\
\text { 은 헤징수단으로 사용 } \\
\text { 될 수 있는가? }\end{array}$ & $\begin{array}{l}\text { 금은 한국과 미국 모두에서 효 } \\
\text { 과적인 헤징수단이다. } \\
\text { 특히 2008년과 같은 국제금 } \\
\text { 융위기에 효과적이다. }\end{array}$ & $\begin{array}{l}\text { 미국에서만이 아니라 우리 } \\
\text { 나라에서도 금은 헤징수 } \\
\text { 단으로서 유용하다. }\end{array}$ \\
\hline
\end{tabular}

\section{〈Appendix IV〉 거래비용을 고려한 결과}

$<$ 표 A2> <표 A8>은 거래비용을 고려하였을 때, 모형의 성능을 분석한 표이다. 거래 비용은 살 때와 팔 때를 모두 고려하여 거래당 2회 $15 \mathrm{bp}$ (basis point)를 적용하였다. <표 A7>, <표 A8>에서 거래비용을 고려하더라도 BLCF 모형이 여전히 시장보다 높은 연평균 수익률을 가지고 있으며, 채권, 환율 등을 이용하여 위험을 회피할 경우, 수익률과 샤프지수는 더욱 증가한다. 
An Investment Strategy Based on Life and Business Cycles

〈표 A2〉 BLCF-Li 모형을 포함한 각각의 지수에 대한 투자수익률 및 샤프지수의 평균치 1975.01.31 2018.05.31 기간 동안의 각각의 지수에 대한 투자수익률 및 샤프지수의 평균치 자료를 투자기간(P1, $\mathrm{P} 2)$ 에 따라 나열해놓은 데이터이다. 지수에 투자할 때와 청산할 때, 각각 $15 \mathrm{bp}$ 의 거래비용을 고려하였으며, 투자시작시점에 따라 투자결과가 다르게 도출될 수 있다는 점을 감안하여 평균치 데이터를 사용하였다. 투자수익률은 년 단위 시간가중수익률로 계산하였다.

\begin{tabular}{llrrrrr}
\hline & & BLCF-Li & BLCF-Li Ex & World & World_Ex & KOSPI \\
\hline \multirow{2}{10}{10} & return & $7.24 \%$ & $8.76 \%$ & $7.33 \%$ & $9.74 \%$ & $7.08 \%$ \\
& sharpe & 0.45 & 0.52 & 0.50 & 0.61 & 0.24 \\
$10 \_15$ & return & $7.40 \%$ & $8.98 \%$ & $7.13 \%$ & $9.33 \%$ & $7.48 \%$ \\
& sharpe & 0.47 & 0.54 & 0.49 & 0.59 & 0.25 \\
$15 \_10$ & return & $7.47 \%$ & $8.84 \%$ & $7.13 \%$ & $9.33 \%$ & $7.48 \%$ \\
& sharpe & 0.46 & 0.52 & 0.49 & 0.59 & 0.25 \\
$10 \_20$ & return & $8.12 \%$ & $9.55 \%$ & $7.35 \%$ & $9.21 \%$ & $8.71 \%$ \\
& sharpe & 0.52 & 0.60 & 0.50 & 0.59 & 0.30 \\
$15 \_15$ & return & $8.25 \%$ & $9.52 \%$ & $7.35 \%$ & $9.21 \%$ & $8.71 \%$ \\
& sharpe & 0.51 & 0.58 & 0.50 & 0.59 & 0.30 \\
$20 \_10$ & return & $8.19 \%$ & $9.24 \%$ & $7.35 \%$ & $9.21 \%$ & $8.71 \%$ \\
& sharpe & 0.48 & 0.54 & 0.50 & 0.59 & 0.30 \\
$15 \_20$ & return & $7.98 \%$ & $9.28 \%$ & $7.45 \%$ & $9.56 \%$ & $8.48 \%$ \\
& sharpe & 0.51 & 0.60 & 0.50 & 0.62 & 0.31 \\
$20 \_15$ & return & $7.95 \%$ & $9.07 \%$ & $7.45 \%$ & $9.56 \%$ & $8.48 \%$ \\
& sharpe & 0.49 & 0.57 & 0.50 & 0.62 & 0.31 \\
$20 \_20$ & return & $7.70 \%$ & $8.98 \%$ & $7.35 \%$ & $9.66 \%$ & $7.79 \%$ \\
& sharpe & 0.51 & 0.60 & 0.50 & 0.64 & 0.30 \\
\hline
\end{tabular}

〈표 A3〉 $\mathrm{n}$ 에 따른 BLCF Ex의 수익률 및 샤프지수

환노출의 가정 하에서 최근 $\mathrm{n}$ 개월 동안의 신흥시장과 글로벌시장의 수익률 갭을 기준으로 투자를 진행하고, 그 펀드의 수익률과 샤프지수를 평균하여 투자기간에 따라 나열한 데이터이다. 데이터는 1975.01.31 2018.05.31 기간 동안의 KOSPI, MSCI World 지수 수익률을 사용하였으며, 지수에 투자할 때와 청산할 때, 각각 $15 \mathrm{bp}$ 의 거래비용을 고려하였다. 환노출의 가정이므로 MSCI World에 대한 투자데이터는 환율의 영향을 그대로 수용하였다. 괄호 밖의 데이터는 투자수익률(년 단위, 시간가중), 괄호 안의 데이터는 샤프지수를 나타낸다.

\begin{tabular}{rcrrrrrrrrrrr}
\hline & 1 & 2 & \multicolumn{1}{c}{3} & \multicolumn{1}{c}{4} & \multicolumn{1}{c}{5} & 6 & 7 & 8 & 9 & 10 & 11 & 12 \\
\hline $10 \_10$ & $9.09 \%$ & $9.51 \%$ & $10.23 \%$ & $10.62 \%$ & $11.31 \%$ & $11.80 \%$ & $12.18 \%$ & $12.18 \%$ & $12.54 \%$ & $12.55 \%$ & $12.31 \%$ & $12.43 \%$ \\
& $(0.54)$ & $(0.55)$ & $(0.59)$ & $(0.60)$ & $(0.63)$ & $(0.65)$ & $(0.67)$ & $(0.66)$ & $(0.68)$ & $(0.68)$ & $(0.66)$ & $(0.66)$ \\
$10 \_15$ & $9.27 \%$ & $9.75 \%$ & $10.38 \%$ & $10.70 \%$ & $11.30 \%$ & $11.57 \%$ & $11.91 \%$ & $12.03 \%$ & $12.32 \%$ & $12.26 \%$ & $11.94 \%$ & $12.08 \%$ \\
& $(0.56)$ & $(0.58)$ & $(0.61)$ & $(0.62)$ & $(0.64)$ & $(0.65)$ & $(0.67)$ & $(0.66)$ & $(0.68)$ & $(0.67)$ & $(0.65)$ & $(0.65)$ \\
$15 \_10$ & $9.18 \%$ & $9.68 \%$ & $10.37 \%$ & $10.70 \%$ & $11.33 \%$ & $11.72 \%$ & $12.08 \%$ & $12.01 \%$ & $12.46 \%$ & $12.33 \%$ & $12.11 \%$ & $12.11 \%$ \\
& $(0.53)$ & $(0.55)$ & $(0.58)$ & $(0.59)$ & $(0.62)$ & $(0.63)$ & $(0.65)$ & $(0.63)$ & $(0.66)$ & $(0.65)$ & $(0.63)$ & $(0.63)$ \\
$10 \_20$ & $9.55 \%$ & $10.00 \%$ & $10.57 \%$ & $10.93 \%$ & $11.45 \%$ & $11.65 \%$ & $11.97 \%$ & $12.19 \%$ & $12.43 \%$ & $12.47 \%$ & $12.10 \%$ & $12.36 \%$ \\
& $(0.59)$ & $(0.61)$ & $(0.64)$ & $(0.66)$ & $(0.68)$ & $(0.67)$ & $(0.69)$ & $(0.70)$ & $(0.71)$ & $(0.70)$ & $(0.68)$ & $(0.69)$ \\
$15 \_15$ & $9.57 \%$ & $10.07 \%$ & $10.70 \%$ & $11.02 \%$ & $11.55 \%$ & $11.81 \%$ & $12.18 \%$ & $12.24 \%$ & $12.63 \%$ & $12.59 \%$ & $12.26 \%$ & $12.38 \%$ \\
& $(0.58)$ & $(0.60)$ & $(0.63)$ & $(0.64)$ & $(0.66)$ & $(0.66)$ & $(0.68)$ & $(0.67)$ & $(0.69)$ & $(0.69)$ & $(0.67)$ & $(0.67)$ \\
$20 \_10$ & $9.43 \%$ & $9.91 \%$ & $10.62 \%$ & $10.94 \%$ & $11.51 \%$ & $11.86 \%$ & $12.28 \%$ & $12.13 \%$ & $12.66 \%$ & $12.52 \%$ & $12.31 \%$ & $12.32 \%$ \\
& $(0.55)$ & $(0.56)$ & $(0.60)$ & $(0.61)$ & $(0.63)$ & $(0.64)$ & $(0.66)$ & $(0.64)$ & $(0.67)$ & $(0.66)$ & $(0.65)$ & $(0.65)$ \\
$15 \_20$ & $9.18 \%$ & $9.56 \%$ & $10.09 \%$ & $10.47 \%$ & $10.93 \%$ & $11.13 \%$ & $11.48 \%$ & $11.68 \%$ & $12.01 \%$ & $12.07 \%$ & $11.68 \%$ & $11.99 \%$ \\
& $(0.59)$ & $(0.60)$ & $(0.63)$ & $(0.64)$ & $(0.66)$ & $(0.66)$ & $(0.68)$ & $(0.68)$ & $(0.70)$ & $(0.69)$ & $(0.67)$ & $(0.68)$ \\
$20 \_15$ & $9.11 \%$ & $9.50 \%$ & $10.12 \%$ & $10.48 \%$ & $10.93 \%$ & $11.19 \%$ & $11.60 \%$ & $11.60 \%$ & $12.07 \%$ & $12.01 \%$ & $11.67 \%$ & $11.85 \%$ \\
& $(0.56)$ & $(0.58)$ & $(0.61)$ & $(0.62)$ & $(0.63)$ & $(0.64)$ & $(0.66)$ & $(0.65)$ & $(0.68)$ & $(0.67)$ & $(0.65)$ & $(0.66)$ \\
$20 \_20$ & $9.02 \%$ & $9.28 \%$ & $9.70 \%$ & $10.03 \%$ & $10.36 \%$ & $10.58 \%$ & $10.94 \%$ & $11.06 \%$ & $11.45 \%$ & $11.48 \%$ & $11.11 \%$ & $11.44 \%$ \\
& $(0.60)$ & $(0.60)$ & $(0.62)$ & $(0.64)$ & $(0.64)$ & $(0.64)$ & $(0.67)$ & $(0.66)$ & $(0.69)$ & $(0.68)$ & $(0.66)$ & $(0.67)$ \\
\hline
\end{tabular}


〈표 A4〉 $\mathrm{n}$ 에 따른 BLCF의 수익률 및 샤프지수

환헤지의 가정 하에서 최근 $\mathrm{n}$ 개월 동안의 신흥시장과 글로벌시장의 수익률 갭을 기준으로 투자를 진행하고, 그 펀드의 수익률과 샤프지수를 평균하여 투자기간에 따라 나열한 데이터이다. 데이터는 1975.01.31 2018.05.31 기간 동안의 KOSPI, MSCI World 지수 수익률을 사용하였으며, 지수에 투자할 때와 청산할 때, 각각 $15 \mathrm{bp}$ 의 거래비용을 고려하였다. 환헤지의 가정이므로, MSCI World에 대한 투자데이터는 환율의 영향을 완전히 제거하였다. 괄호 밖의 데이터는 투자수익률(년 단위, 시간가중), 괄호 안의 데이터는 샤프지수를 나타낸다.

\begin{tabular}{rcrrrrrrrrrrr}
\hline & 1 & 2 & \multicolumn{1}{c}{3} & \multicolumn{1}{c}{4} & \multicolumn{1}{c}{5} & 6 & 7 & 8 & 9 & 10 & 11 & 12 \\
\hline $10 \_10$ & $9.09 \%$ & $9.51 \%$ & $10.23 \%$ & $10.62 \%$ & $11.31 \%$ & $11.80 \%$ & $12.18 \%$ & $12.18 \%$ & $12.54 \%$ & $12.55 \%$ & $12.31 \%$ & $12.43 \%$ \\
& $(0.54)$ & $(0.55)$ & $(0.59)$ & $(0.60)$ & $(0.63)$ & $(0.65)$ & $(0.67)$ & $(0.66)$ & $(0.68)$ & $(0.68)$ & $(0.66)$ & $(0.66)$ \\
$10 \_15$ & $9.27 \%$ & $9.75 \%$ & $10.38 \%$ & $10.70 \%$ & $11.30 \%$ & $11.57 \%$ & $11.91 \%$ & $12.03 \%$ & $12.32 \%$ & $12.26 \%$ & $11.94 \%$ & $12.08 \%$ \\
& $(0.56)$ & $(0.58)$ & $(0.61)$ & $(0.62)$ & $(0.64)$ & $(0.65)$ & $(0.67)$ & $(0.66)$ & $(0.68)$ & $(0.67)$ & $(0.65)$ & $(0.65)$ \\
$15 \_10$ & $9.18 \%$ & $9.68 \%$ & $10.37 \%$ & $10.70 \%$ & $11.33 \%$ & $11.72 \%$ & $12.08 \%$ & $12.01 \%$ & $12.46 \%$ & $12.33 \%$ & $12.11 \%$ & $12.11 \%$ \\
& $(0.53)$ & $(0.55)$ & $(0.58)$ & $(0.59)$ & $(0.62)$ & $(0.63)$ & $(0.65)$ & $(0.63)$ & $(0.66)$ & $(0.65)$ & $(0.63)$ & $(0.63)$ \\
$10 \_20$ & $9.55 \%$ & $10.00 \%$ & $10.57 \%$ & $10.93 \%$ & $11.45 \%$ & $11.65 \%$ & $11.97 \%$ & $12.19 \%$ & $12.43 \%$ & $12.47 \%$ & $12.10 \%$ & $12.36 \%$ \\
& $(0.59)$ & $(0.61)$ & $(0.64)$ & $(0.66)$ & $(0.68)$ & $(0.67)$ & $(0.69)$ & $(0.70)$ & $(0.71)$ & $(0.70)$ & $(0.68)$ & $(0.69)$ \\
$15 \_15$ & $9.57 \%$ & $10.07 \%$ & $10.70 \%$ & $11.02 \%$ & $11.55 \%$ & $11.81 \%$ & $12.18 \%$ & $12.24 \%$ & $12.63 \%$ & $12.59 \%$ & $12.26 \%$ & $12.38 \%$ \\
& $(0.58)$ & $(0.60)$ & $(0.63)$ & $(0.64)$ & $(0.66)$ & $(0.66)$ & $(0.68)$ & $(0.67)$ & $(0.69)$ & $(0.69)$ & $(0.67)$ & $(0.67)$ \\
$20 \_10$ & $9.43 \%$ & $9.91 \%$ & $10.62 \%$ & $10.94 \%$ & $11.51 \%$ & $11.86 \%$ & $12.28 \%$ & $12.13 \%$ & $12.66 \%$ & $12.52 \%$ & $12.31 \%$ & $12.32 \%$ \\
& $(0.55)$ & $(0.56)$ & $(0.60)$ & $(0.61)$ & $(0.63)$ & $(0.64)$ & $(0.66)$ & $(0.64)$ & $(0.67)$ & $(0.66)$ & $(0.65)$ & $(0.65)$ \\
$15 \_20$ & $9.18 \%$ & $9.56 \%$ & $10.09 \%$ & $10.47 \%$ & $10.93 \%$ & $11.13 \%$ & $11.48 \%$ & $11.68 \%$ & $12.01 \%$ & $12.07 \%$ & $11.68 \%$ & $11.99 \%$ \\
& $(0.59)$ & $(0.60)$ & $(0.63)$ & $(0.64)$ & $(0.66)$ & $(0.66)$ & $(0.68)$ & $(0.68)$ & $(0.70)$ & $(0.69)$ & $(0.67)$ & $(0.68)$ \\
$20 \_15$ & $9.11 \%$ & $9.50 \%$ & $10.12 \%$ & $10.48 \%$ & $10.93 \%$ & $11.19 \%$ & $11.60 \%$ & $11.60 \%$ & $12.07 \%$ & $12.01 \%$ & $11.67 \%$ & $11.85 \%$ \\
& $(0.56)$ & $(0.58)$ & $(0.61)$ & $(0.62)$ & $(0.63)$ & $(0.64)$ & $(0.66)$ & $(0.65)$ & $(0.68)$ & $(0.67)$ & $(0.65)$ & $(0.66)$ \\
$20 \_20$ & $9.02 \%$ & $9.28 \%$ & $9.70 \%$ & $10.03 \%$ & $10.36 \%$ & $10.58 \%$ & $10.94 \%$ & $11.06 \%$ & $11.45 \%$ & $11.48 \%$ & $11.11 \%$ & $11.44 \%$ \\
& $(0.60)$ & $(0.60)$ & $(0.62)$ & $(0.64)$ & $(0.64)$ & $(0.64)$ & $(0.67)$ & $(0.66)$ & $(0.69)$ & $(0.68)$ & $(0.66)$ & $(0.67)$ \\
\hline
\end{tabular}

\section{〈표 A5〉 Vintage 수익률 및 샤프지수}

Vintage 수익률 및 샤프지수의 기술적 분석 데이터로, Vintage 수익률과 샤프지수의 평균, 표준편차, quantile을 나타낸다. 데이터는 1975.01.31 2018.05.31 기간 동안의 KOSPI, MSCI World 지수 수익률을 사용하였으며, 지수에 투자할 때와 청산할 때, 각각 $15 \mathrm{bp}$ 의 거래비용을 고려하였다.

\begin{tabular}{|c|c|c|c|c|c|c|c|c|}
\hline & & mean & std & $\min (=0)$ & 0.25 & 0.5 & 0.75 & $\max (=1)$ \\
\hline \multirow[t]{2}{*}{ 10_10 } & return & $12.54 \%$ & 0.05 & $5.64 \%$ & $7.91 \%$ & $13.46 \%$ & $17.61 \%$ & $20.13 \%$ \\
\hline & sharpe & 0.68 & 0.27 & 0.29 & 0.40 & 0.70 & 0.93 & 1.10 \\
\hline \multirow[t]{2}{*}{ 10_15 } & return & $12.32 \%$ & 0.03 & $6.55 \%$ & $8.53 \%$ & $14.07 \%$ & $15.01 \%$ & $16.83 \%$ \\
\hline & sharpe & 0.68 & 0.18 & 0.37 & 0.48 & 0.73 & 0.82 & 1.02 \\
\hline \multirow[t]{2}{*}{ 15_10 } & return & $12.46 \%$ & 0.04 & $6.29 \%$ & $8.46 \%$ & $14.26 \%$ & $15.46 \%$ & $17.28 \%$ \\
\hline & sharpe & 0.66 & 0.19 & 0.33 & 0.45 & 0.72 & 0.81 & 1.01 \\
\hline \multirow[t]{2}{*}{ 10_20 } & return & $12.43 \%$ & 0.01 & $7.90 \%$ & $11.97 \%$ & $12.85 \%$ & $13.38 \%$ & $14.02 \%$ \\
\hline & sharpe & 0.71 & 0.08 & 0.46 & 0.68 & 0.72 & 0.74 & 0.85 \\
\hline \multirow[t]{2}{*}{ 15_15 } & return & $12.63 \%$ & 0.01 & $7.66 \%$ & $12.50 \%$ & $13.09 \%$ & $13.40 \%$ & $14.36 \%$ \\
\hline & sharpe & 0.69 & 0.09 & 0.43 & 0.68 & 0.70 & 0.73 & 0.85 \\
\hline \multirow[t]{2}{*}{ 20_10 } & return & $12.66 \%$ & 0.02 & $7.67 \%$ & $12.49 \%$ & $13.05 \%$ & $13.37 \%$ & $14.52 \%$ \\
\hline & sharpe & 0.67 & 0.09 & 0.41 & 0.66 & 0.68 & 0.71 & 0.83 \\
\hline \multirow[t]{2}{*}{ 15_20 } & return & $12.01 \%$ & 0.00 & $11.09 \%$ & $11.81 \%$ & $12.05 \%$ & $12.33 \%$ & $12.88 \%$ \\
\hline & sharpe & 0.70 & 0.03 & 0.64 & 0.68 & 0.70 & 0.71 & 0.76 \\
\hline \multirow[t]{2}{*}{ 20_15 } & return & $12.07 \%$ & 0.00 & $11.22 \%$ & $11.90 \%$ & $12.16 \%$ & $12.32 \%$ & $12.93 \%$ \\
\hline & sharpe & 0.68 & 0.03 & 0.63 & 0.66 & 0.68 & 0.70 & 0.74 \\
\hline \multirow[t]{2}{*}{ 20_20 } & return & $11.45 \%$ & 0.00 & $10.82 \%$ & $11.38 \%$ & $11.52 \%$ & $11.61 \%$ & $11.85 \%$ \\
\hline & sharpe & 0.69 & 0.02 & 0.64 & 0.68 & 0.69 & 0.70 & 0.72 \\
\hline
\end{tabular}


An Investment Strategy Based on Life and Business Cycles

〈표 A6〉각각의 지수에 대한 투자수익률 및 샤프지수의 평균치

투자기간(P1,P2)에 따라 각각의 지수에 투자하였을 때, 투자수익률(년 단위, 시간가중) 및 샤프지수의 평균치 데이터이다. 데이터는 1975.01.31 2018.05.31 기간 동안의 KOSPI, MSCI World 지수 수익률을 사용하였으며, 지수에 투자할 때와 청산할 때, 각각 $15 \mathrm{bp}$ 의 거래비용을 고려하였다. 투자시작시점에 따라 투자결과가 다르게 도출될 수 있다는 점을 감안하여 평균치 데이터를 사용하여 분석하였다.

\begin{tabular}{llrrrrrrr}
\hline \multirow{2}{*}{ KP } & & mean & std & $\min (=0)$ & 0.25 & 0.5 & 0.75 & $\max (=1)$ \\
\multirow{2}{*}{ World } & return & $8.71 \%$ & 0.01 & $4.46 \%$ & $8.51 \%$ & $9.23 \%$ & $9.56 \%$ & $10.41 \%$ \\
& sharpe & 0.30 & 0.05 & 0.16 & 0.29 & 0.32 & 0.33 & 0.36 \\
\multirow{2}{*}{ World_Ex } & return & $7.35 \%$ & 0.01 & $4.67 \%$ & $6.84 \%$ & $7.43 \%$ & $7.96 \%$ & $9.64 \%$ \\
& sharpe & 0.50 & 0.10 & 0.31 & 0.45 & 0.48 & 0.52 & 0.70 \\
\multirow{2}{*}{ BLCF } & return & $9.21 \%$ & 0.02 & $5.83 \%$ & $8.35 \%$ & $9.12 \%$ & $10.80 \%$ & $11.96 \%$ \\
& sharpe & 0.59 & 0.10 & 0.39 & 0.55 & 0.58 & 0.66 & 0.75 \\
\multirow{2}{*}{ BLCF_Ex } & return & $9.71 \%$ & 0.01 & $6.04 \%$ & $9.04 \%$ & $10.01 \%$ & $10.62 \%$ & $11.36 \%$ \\
& sharpe & 0.57 & 0.08 & 0.35 & 0.52 & 0.58 & 0.61 & 0.71 \\
BLCF_Li & return & $12.43 \%$ & 0.01 & $7.90 \%$ & $11.97 \%$ & $12.85 \%$ & $13.38 \%$ & $14.02 \%$ \\
& sharpe & 0.71 & 0.08 & 0.46 & 0.68 & 0.72 & 0.74 & 0.85 \\
\multirow{2}{*}{ BLCF_Li_Ex } & return & $8.12 \%$ & 0.01 & $4.86 \%$ & $7.55 \%$ & $8.39 \%$ & $8.90 \%$ & $9.93 \%$ \\
& return & $9.55 \%$ & 0.01 & $5.96 \%$ & $8.94 \%$ & $9.71 \%$ & $10.34 \%$ & $11.38 \%$ \\
& sharpe & 0.60 & 0.07 & 0.38 & 0.56 & 0.61 & 0.65 & 0.70 \\
\hline
\end{tabular}

〈표 A7〉 BLCF-H 평균 수익률 및 평균 샤프지수

각각의 모형에 투자하였을 때, 투자수익률(시간가중) 및 샤프지수의 평균치 데이터이다. 데이터는 1975.01.31 2018.05.31 기간 동안의 KOSPI, MSCI World 지수 수익률을 사용하였으며, 지수에 투자할 때와 청산할 때, 각각 $15 \mathrm{bp}$ 의 거래비용을 고려하였다. 투자시작시점에 따라 투자결과가 다르게 도출될 수 있다는 점을 감안하여 평균치 데이터를 사용하여 분석하였다.

\begin{tabular}{|c|c|c|c|c|c|c|c|c|}
\hline & & mean & std & $\min (=0)$ & 0.25 & 0.5 & 0.75 & $\max (=1)$ \\
\hline \multirow[t]{2}{*}{$\mathrm{BLCF}-\mathrm{H}$ (Gold) } & return & $8.77 \%$ & 0.0141 & $5.86 \%$ & $7.91 \%$ & $8.47 \%$ & $9.78 \%$ & $11.20 \%$ \\
\hline & sharpe & 0.55 & 0.0705 & 0.39 & 0.52 & 0.56 & 0.60 & 0.67 \\
\hline \multirow[t]{2}{*}{$\mathrm{BLCF}-\mathrm{H}$ (Bond) } & return & $10.20 \%$ & 0.0138 & $6.96 \%$ & $9.39 \%$ & $10.19 \%$ & $11.33 \%$ & $12.33 \%$ \\
\hline & sharpe & 0.71 & 0.0749 & 0.51 & 0.65 & 0.74 & 0.77 & 0.81 \\
\hline \multirow[t]{2}{*}{$\mathrm{BLCF}-\mathrm{H}(\mathrm{Ex})$} & return & $13.01 \%$ & 0.0160 & $9.77 \%$ & $11.79 \%$ & $13.17 \%$ & $14.36 \%$ & $15.44 \%$ \\
\hline & sharpe & 0.79 & 0.0666 & 0.62 & 0.74 & 0.81 & 0.84 & 0.88 \\
\hline \multirow[t]{2}{*}{ BLCF } & return & $9.71 \%$ & 0.0127 & $6.04 \%$ & $9.04 \%$ & $10.01 \%$ & $10.62 \%$ & $11.36 \%$ \\
\hline & sharpe & 0.57 & 0.0846 & 0.35 & 0.52 & 0.58 & 0.61 & 0.71 \\
\hline \multirow[t]{2}{*}{ KOSPI } & return & $8.71 \%$ & 0.0136 & $4.46 \%$ & $8.51 \%$ & $9.23 \%$ & $9.56 \%$ & $10.41 \%$ \\
\hline & sharpe & 0.30 & 0.0453 & 0.16 & 0.29 & 0.32 & 0.33 & 0.36 \\
\hline \multirow[t]{2}{*}{ MSCI World } & return & $7.35 \%$ & 0.0123 & $4.67 \%$ & $6.84 \%$ & $7.43 \%$ & $7.96 \%$ & $9.64 \%$ \\
\hline & sharpe & 0.50 & 0.0980 & 0.31 & 0.45 & 0.48 & 0.52 & 0.70 \\
\hline
\end{tabular}

